Prepared in cooperation with North Dakota Department of Transportation, North Dakota State Water Commission and U.S. Army Corps of Engineers

\title{
Use of a Two-Dimensional Hydrodynamic Model to Evaluate Extreme Flooding and Transport of Dissolved Solids through Devils Lake and Stump Lake, North Dakota, 2006
}

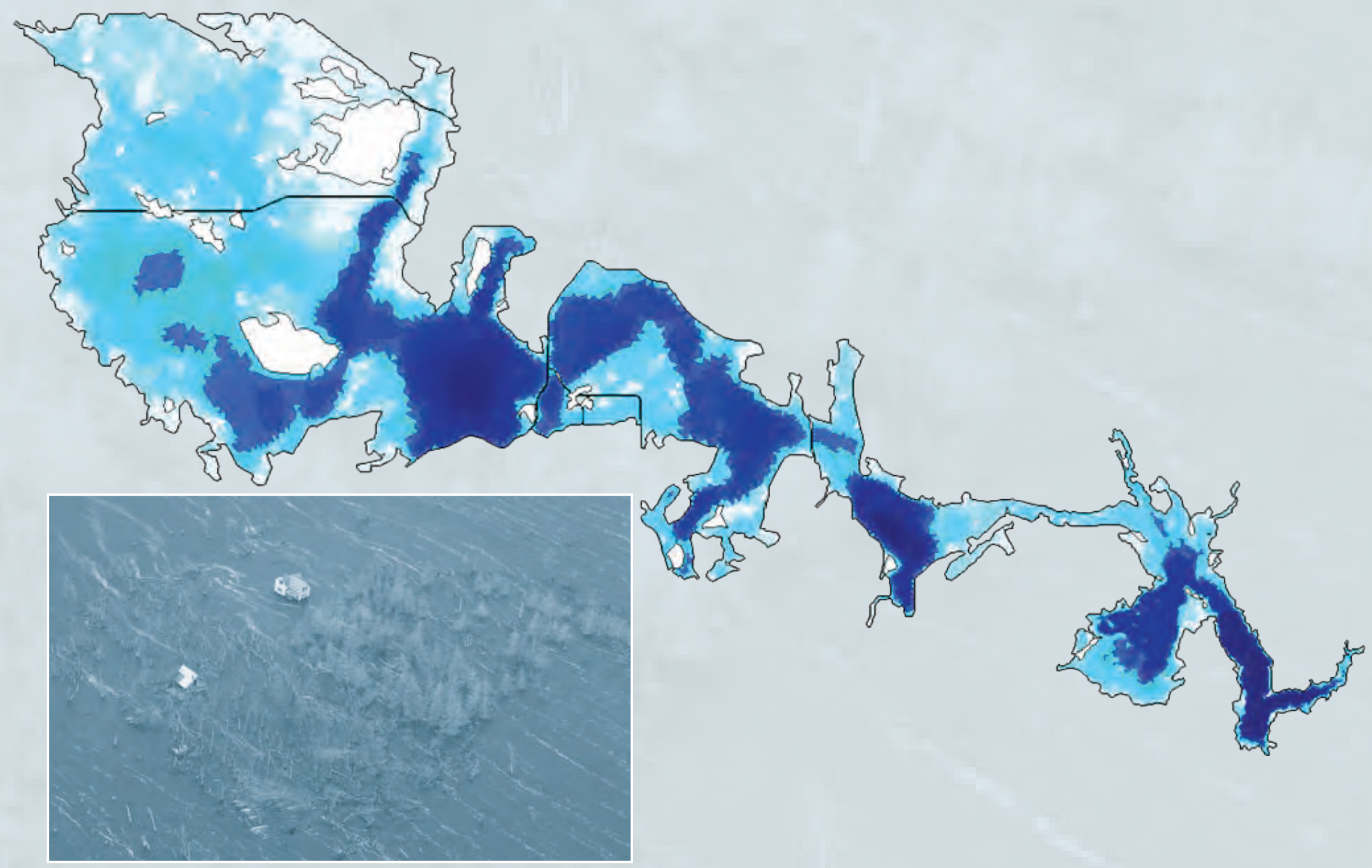

Scientific Investigations Report 2011-5035 
Front cover: Farmstead consumed by rising waters from Devils Lake (photograph by Ralph T. Cheng, U.S. Geological Survey, 2007). 


\section{Use of a Two-Dimensional Hydrodynamic Model to Evaluate Extreme Flooding and Transport of Dissolved Solids through Devils Lake and Stump Lake, North Dakota, 2006}

By Rochelle A. Nustad, Tamara M. Wood, and Jerad D. Bales

Prepared in cooperation with North Dakota Department of Transportation, North Dakota State Water Commission and U.S. Army Corps of Engineers

Scientific Investigations Report 2011-5035 


\section{U.S. Department of the Interior \\ KEN SALAZAR, Secretary \\ U.S. Geological Survey \\ Marcia K. McNutt, Director}

\section{U.S. Geological Survey, Reston, Virginia: 2011}

For more information on the USGS — the Federal source for science about the Earth, its natural and living resources, natural hazards, and the environment, visit http://www.usgs.gov or call 1-888-ASK-USGS.

For an overview of USGS information products, including maps, imagery, and publications, visit http://www.usgs.gov/pubprod

Any use of trade, product, or firm names is for descriptive purposes only and does not imply endorsement by the U.S. Government.

Although this report is in the public domain, permission must be secured from the individual copyright owners to reproduce any copyrighted materials contained within this report.

Suggested citation:

Nustad, R.A., Wood,T.M., and Bales, J.D., 2011, Use of a two-dimensional hydrodynamic model to evaluate extreme flooding and transport of dissolved solids through Devils Lake and Stump Lake, North Dakota, 2006: U.S. Geological Survey Scientific Investigations Report 2011-5035, 33 p. 


\section{Acknowledgments}

Dan Sauter (North Dakota State Water Commission) surveyed lake datums for data collection sites. Jonathan Petersen (U.S. Army Corps of Engineers) provided boundary conditions and assumptions for the extreme flooding scenario. Brian Connelly (National Weather Service) provided estimates for 2009 inflows.

Collection and analysis of the 2006 data by William Damschen and Brent Hanson (U.S. Geological Survey, North Dakota Water Science Center) is gratefully acknowledged. Skip Vecchia (U.S. Geological Survey, North Dakota Water Science Center) provided assistance and guidance throughout the investigation. Joel Galloway (U.S. Geological Survey, North Dakota Water Science Center) compiled contour data for Stump Lake.

\section{Contents}

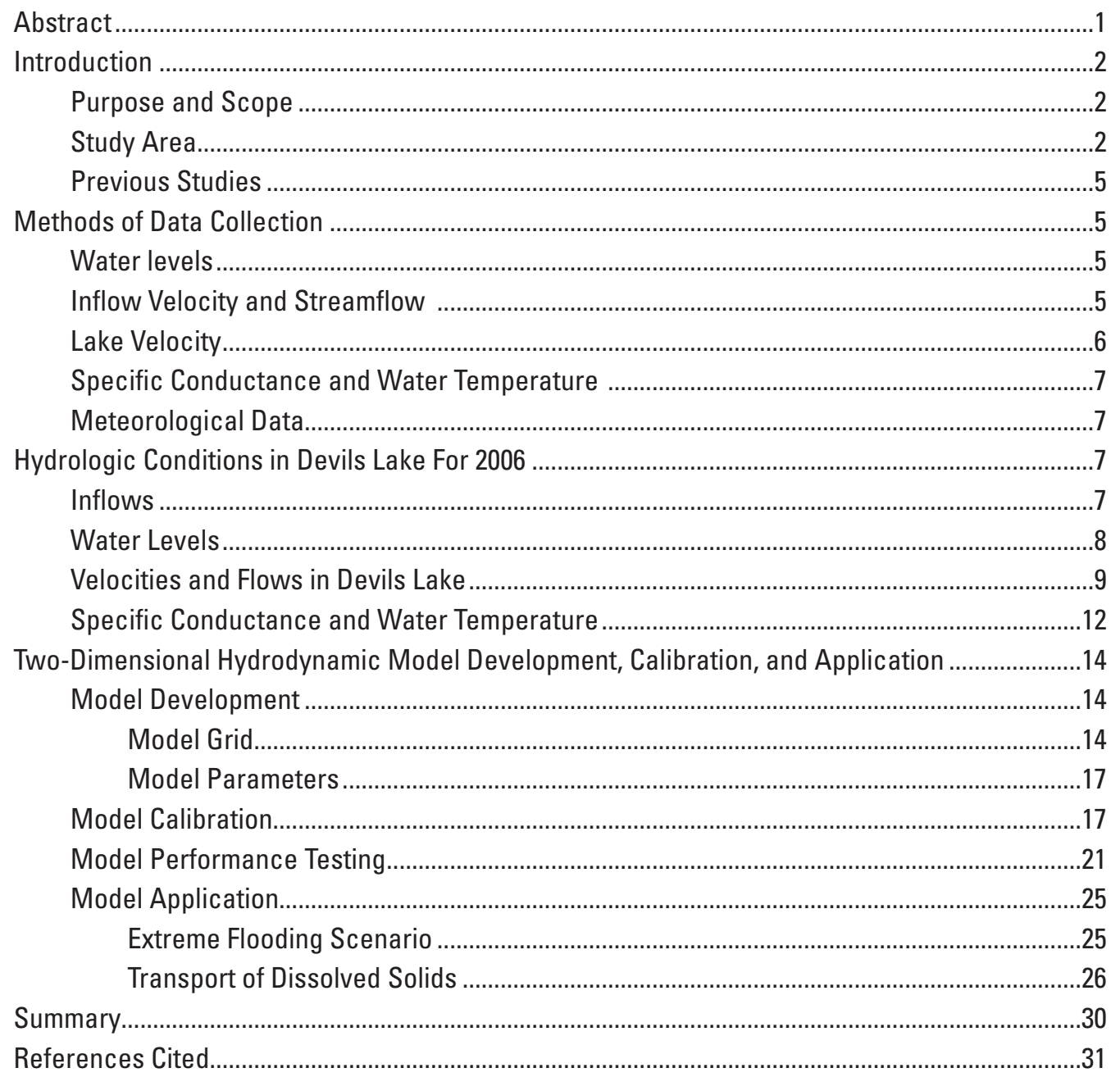




\section{Figures}

1. Map showing location of data collection sites in Devils Lake, North Dakota, 2006

2. Graph showing historic water levels of Devils Lake near Devils Lake, North Dakota. .4

3. Graph showing measured inflows to Devils Lake, North Dakota and precipitation measured at the Crary 1E North Dakota Agricultural Weather Network station, located near Crary, North Dakota, 2006

4. Graph showing estimated annual inflow to Devils Lake for 1950 through 2009

5. Graph showing hourly water levels measured at selected sites in Devils Lake and Stump Lake, North Dakota, 2006.

6. Graphs showing wind speed and direction measured at the Crary $1 \mathrm{E}$ North Dakota Agricultural Weather Network weather station, located near Crary, North Dakota, April 1 through September 30, 2006

7. Graphs showing water levels in Devils Lake, North Dakota at sites 10 and 11, and wind speed and direction measured at the Crary $1 \mathrm{E}$ North Dakota Agricultural Weather Network weather station, located near Crary, North Dakota from June 7 through June 23, 2006

8. Graph showing average annual water level for Devils Lake, North Dakota at site 1

9. Graph showing effect of wind on flow through bridge opening at site 8, July 11, 2006

10. Graphs showing continuously measured specific conductance and water temperature in Devils Lake, North Dakota, 2006

11. Graphs showing specific conductance and water temperature measured at four depths at site 8 in Devils Lake, North Dakota, 2006

12. Map showing unstructured orthogonal model grid of the Devils Lake model showing inflow and outflow locations, close up view of bridge opening at State Highway 19 (site 6), and areas used for initialization of water levels

13. Graphs showing simulated and measured water levels for selected sites on Devils Lake and Stump Lake, North Dakota, April 1 through September 30, 2006.

14. Graphs showing simulated and measured water levels for selected sites on Devils Lake and Stump Lake, North Dakota, June 7 through 23, 2006

15. Graphs showing simulated and measured current speed and direction for Devils Lake, North Dakota at site 8, April 1 through September 30, 2006.

16. Graphs showing simulated and measured current speed and direction for Devils Lake, North Dakota at site 12, April 1 through September 30, 2006.

17. Graphs showing simulated and measured water levels for Devils Lake (site 1) and Stump Lake (site 13), North Dakota, April 1 through September 30, 2009.

18. Graph showing estimated daily inflows to Devils Lake, North Dakota and precipitation measured at the Crary 1E North Dakota Agricultural Weather Network station, located near Crary, North Dakota, 2009

19. Graph showing simulated water levels using the Devils Lake model for sites on Devils Lake (site 1 and embankment) and Stump Lake (site 13), North Dakota for an extreme flooding scenario

20. Map showing areas in the model grid of the Devils Lake model, North Dakota used for specifying initial specific conductance concentrations 


\section{Tables}

1. Data collection sites for Devils Lake, North Dakota, 2006 ............................................6

2. Statistical properties of select parameters from acoustic velocity meters (AVMs) located in Devils Lake, North Dakota at sites 8 and 12 ......................................11

3. Mid-month multiplier applied to potential evapotranspiration data. ..............................18

4. Goodness-of-fit water-level statistics for the calibration of the Devils Lake model, North Dakota, April 1 through September 30, 2006 ............................................20

5. Goodness-of-fit current speed statistics for the calibration of the Devils Lake model, North Dakota, April 1 through September 30, 2006 .............................................21

6. Inflow volumes and locations used for an extreme flooding scenario in the Devils Lake model.

7. Maximum and mean simulated water levels for an extreme flooding scenario using the Devils Lake model for sites on Devils Lake (site 1 and embankment) and Stump Lake (site 13).

8. Comparison of simulated water-level results for Devils Lake (site 1) and Stump Lake, North Dakota (site 13) for four changes in conditions in the Devils Lake model for an extreme flooding scenario.

9. Boundary conditions used for simulation of specific conductance for different scenarios in Devils Lake, North Dakota.

10. Simulated effects of hydrological modifications on specific conductance concentrations for West Bay and Main Bay in Devils Lake, North Dakota 


\section{Conversion Factors}

Inch/Pound to SI

\begin{tabular}{|c|c|c|}
\hline Multiply & By & To obtain \\
\hline \multicolumn{3}{|c|}{ Length } \\
\hline inch (in.) & 2.54 & centimeter $(\mathrm{cm})$ \\
\hline inch (in.) & 25.4 & millimeter $(\mathrm{mm})$ \\
\hline foot $(\mathrm{ft})$ & .3048 & meter $(\mathrm{m})$ \\
\hline mile (mi) & 1.609 & kilometer $(\mathrm{km})$ \\
\hline mile, nautical (nmi) & 1.852 & kilometer $(\mathrm{km})$ \\
\hline yard (yd) & .9144 & meter $(\mathrm{m})$ \\
\hline \multicolumn{3}{|c|}{ Area } \\
\hline square foot $\left(\mathrm{ft}^{2}\right)$ & 0.09290 & square meter $\left(\mathrm{m}^{2}\right)$ \\
\hline square inch $\left(\mathrm{in}^{2}\right)$ & 6.452 & square centimeter $\left(\mathrm{cm}^{2}\right)$ \\
\hline square mile $\left(\mathrm{mi}^{2}\right)$ & 259.0 & hectare (ha) \\
\hline square mile $\left(\mathrm{mi}^{2}\right)$ & 2.590 & square kilometer $\left(\mathrm{km}^{2}\right)$ \\
\hline \multicolumn{3}{|c|}{ Volume } \\
\hline cubic foot $\left(\mathrm{ft}^{3}\right)$ & 0.02832 & cubic meter $\left(\mathrm{m}^{3}\right)$ \\
\hline acre-foot (acre-ft) & 1,233 & cubic meter $\left(\mathrm{m}^{3}\right)$ \\
\hline \multicolumn{3}{|c|}{ Flow rate } \\
\hline foot per second (ft/s) & 0.3048 & meter per second $(\mathrm{m} / \mathrm{s})$ \\
\hline cubic foot per second $\left(\mathrm{ft}^{3} / \mathrm{s}\right)$ & .02832 & cubic meter per second $\left(\mathrm{m}^{3} / \mathrm{s}\right)$ \\
\hline
\end{tabular}

Temperature in degrees Celsius $\left({ }^{\circ} \mathrm{C}\right)$ may be converted to degrees Fahrenheit $\left({ }^{\circ} \mathrm{F}\right)$ as follows:

$$
{ }^{\circ} \mathrm{F}=\left(1.8 x^{\circ} \mathrm{C}\right)+32
$$

Vertical coordinate information is referenced to the National Geodetic Vertical Datum of 1929 (NGVD 29).

Horizontal coordinate information is referenced to the North American Datum of 1983 (NAD 83).

Elevation, as used in this report, refers to distance above the vertical datum. 


\title{
Use of a Two-Dimensional Hydrodynamic Model to Evaluate Extreme Flooding and Transport of Dissolved Solids through Devils Lake and Stump Lake, North Dakota, 2006
}

\author{
By Rochelle A. Nustad, Tamara M. Wood, and Jerad D. Bales
}

\begin{abstract}
The U.S. Geological Survey in cooperation with the North Dakota Department of Transportation, North Dakota State Water Commission, and U.S. Army Corps of Engineers, developed a two-dimensional hydrodynamic model of Devils Lake and Stump Lake, North Dakota to be used as a hydrologic tool for evaluating the effects of different inflow scenarios on water levels, circulation, and the transport of dissolved solids through the lake. The numerical model, UnTRIM, and data primarily collected during 2006 were used to develop and calibrate the Devils Lake model. Performance of the Devils Lake model was tested using 2009 data. The Devils Lake model was applied to evaluate the effects of an extreme flooding event on water levels and hydrological modifications within the lake on the transport of dissolved solids through Devils Lake and Stump Lake.
\end{abstract}

For the 2006 calibration, simulated water levels in Devils Lake compared well with measured water levels. The maximum simulated water level at site 1 was within 0.13 feet of the maximum measured water level in the calibration, which gives reasonable confidence that the Devils Lake model is able to accurately simulate the maximum water level at site 1 for the extreme flooding scenario. The timing and direction of winddriven fluctuations in water levels on a short time scale (a few hours to a day) were reproduced well by the Devils Lake model. For this application, the Devils Lake model was not optimized for simulation of the current speed through bridge openings. In future applications, simulation of current speed through bridge openings could be improved by more accurate definition of the bathymetry and geometry of select areas in the model grid.

As a test of the performance of the Devils Lake model, a simulation of 2009 conditions from April 1 through September 30, 2009 was performed. Overall, errors in inflow estimates affected the results for the 2009 simulation; however, for the rising phase of the lakes, the Devils Lake model accurately simulated the faster rate of rise in Devils Lake than in Stump
Lake, and timing and direction of wind-driven fluctuations in water levels on a short time scale were reproduced well.

To help the U.S. Army Corps of Engineers determine the elevation to which the protective embankment for the city of Devils Lake should be raised, an extreme flooding scenario based on an inflow of one-half the probable maximum flood was simulated. Under the conditions and assumptions of the extreme flooding scenario, the water level for both lakes reached a maximum water level around 1,461.9 feet above the National Geodetic Vertical Datum of 1929.

One factor limiting the extent of pumping from the Devils Lake State Outlet is sulfate concentrations in West Bay. If sulfate concentrations can be reduced in West Bay, pumping from the Devils Lake State Outlet potentially can increase. The Devils Lake model was used to simulate the transport of dissolved solids using specific conductance data as a surrogate for sulfate. Because the transport of dissolved solids was not calibrated, results from the simulations were not actual expected concentrations. However, the effects of hydrological modifications on the transport of dissolved solids could be evaluated by comparing the effects of hydrological modifications relative to a baseline scenario in which no hydrological modifications were made. Four scenarios were simulated: (1) baseline condition (no hydrological modification), (2) diversion of Channel A, (3) reduction of the area of water exchange between Main Bay and East Bay, and (4) combination of scenarios 2 and 3. Relative to scenario 1, mean concentrations in West Bay for scenarios 2 and 4 were reduced by approximately 9 percent. Given that there is no change in concentration for scenario 3 , but about a 9-percent reduction in concentration for scenario 4, the diversion of Channel A was the only hydrologic modification that appeared to have the potential to reduce sulfate concentrations in West Bay. 


\section{Introduction}

The Devils Lake Basin is a 3,810-square-mile ( $\mathrm{mi}^{2}$ ) subbasin of the Red River of the North Basin (fig. 1). The Devils Lake Basin contains several small interconnected lakes, often referred to as the chain of lakes (Sweetwater Lake, Morrison Lake, Dry Lake, Mikes Lake, Chain Lake, Lake Alice, and Lake Irvine), and two large lakes, Devils Lake and Stump Lake. About 3,320 $\mathrm{mi}^{2}$ of the total basin area (which includes the chain of lakes) drains directly to Devils Lake, with the remainder draining directly to Stump Lake. At water levels less than 1446.5 feet (ft), Devils Lake is a terminal lake, and the Devils Lake Basin is a closed basin at water levels in Devils Lake less than 1,458.0 ft above the National Geodetic Vertical Datum of 1929 (NGVD 29). Unless stated otherwise, all water levels in this report will be with respect to NGVD 29. At water levels greater than 1,446.5 ft, Devils Lake spills to Stump Lake, and at water levels greater than $1458.0 \mathrm{ft}$, Devils Lake and Stump Lake together begin to spill through the Tolna Coulee to the Sheyenne River (North Dakota State Water Commission, 2010). Geologic and other records suggest that Devils Lake has been a dry lake in the past, but also has spilled to the Sheyenne River at least twice during the last 4,000 years (Bluemle, 1991; Murphy and others, 1997).

Water levels were measured occasionally between 1867 and 1901, but regularly since 1901 (fig. 2). The minimum recorded water level of 1,400.9 ft for Devils Lake occurred in 1940, with a corresponding surface area of 6,400 acres (U.S. Geological Survey [USGS] station number 05056500; http:// waterdata.usgs.gov/nwis/; http://nd.water.usgs.gov/devilslake/ pdflelevation-area-volume.pdf, accessed March 14, 2011). Generally, water levels were rising from 1940 to 1956, falling from 1956 to 1968, rising and peaking at 1,428.0 ft in 1983 and 1987, and then falling through 1992; the most recent low level was 1,422.4 ft (October 31, 1992). Since 1993, Devils Lake has been experiencing an unprecedented rise in water levels (since water levels have been measured in the late 1800s) (fig. 2). The water level of Devils Lake has exceeded $1,446.5 \mathrm{ft}$ (spill elevation to Stump Lake) more or less continuously since May 1999. In June 2010, the water level reached $1,452.0 \mathrm{ft}$.

From March 1993 (1422.7 ft) to the peak water level in June 2010 (1,452.0 ft), the surface area of Devils Lake nearly quadrupled in size from 44,470 acres to 165,500 acres, and during the same period, the volume of the lake increased more than five times from 570,200 acre-foot (acre-ft) to about 3.1 million acre-ft (MAF) (http://nd.water.usgs.gov/devilslake/pdf/ elevation-area-volume.pdf, accessed March 14, 2011).

Direct flood damages and flood mitigation measures associated with the rise in Devils Lake have cost about 852 million dollars (Report of the Federal Interagency Devils Lake Working Group, 2010). Farmland has been lost, the dike protecting the town of Devils Lake has been raised and lengthened multiple times, the community of Minnewaukan is threatened, roads have been inundated or raised, and transportation patterns have been disrupted. As the lake continues to rise and economic loss increases, the need for hydrologic tools that can be used in planning flood mitigation measures has increased. The USGS, in cooperation with the North Dakota Department of Transportation (NDDOT), North Dakota State Water Commission (NDSWC), and U.S. Army Corps of Engineers (USACE), developed a numerical model of Devils Lake to use as a hydrologic tool for evaluating the effects of different inflow scenarios on water levels, circulation, and the transport of dissolved solids through the lake.

\section{Purpose and Scope}

The purpose of this report is to document the development, calibration, and application of the two-dimensional, hydrodynamic model, UnTRIM, for Devils Lake and Stump Lake, North Dakota. Data primarily collected during 2006 were used to develop and calibrate the model (hereafter referred to as the Devils Lake model). Hydrologic conditions in Devils Lake during 2006 are described using water-level, velocity, and flow data collected throughout the lake. Performance of the Devils Lake model was tested using 2009 data. The Devils Lake model was applied to evaluate the effects of an extreme flooding event on water levels and hydrological modifications within the lake on the transport of dissolved solids through Devils Lake and Stump Lake. The study area includes part of the chain of lakes, Devils Lake, the Jerusalem Outlet, Stump Lake and the tributaries of Big Coulee, Channel A, and Little Coulee (fig.1).

\section{Study Area}

Geologic features in the Devils Lake Basin are the result of continental glaciation, which ended about 10,000 years ago (Aronow, 1957; Bluemle, 1991). Since glaciation, the water level of Devils Lake has fluctuated from about $1,400 \mathrm{ft}$, to about $1,458 \mathrm{ft}$, the natural spill elevation of the lake. Several studies have concluded that large and frequent water-level fluctuations from 20 to $40 \mathrm{ft}$ have occurred every few hundred years (Murphy and others, 1997; Vecchia, 2008). Rising and falling water levels seem to be the natural condition of Devils Lake rather than a stable level (Bluemle, 1991). Recently (since the late 1970s) the water level is generally in a rising phase (fig. 2). Water levels rose $23.5 \mathrm{ft}$ from 1,423.0 ft in 1992 to 1,446.5 feet in May of 1999 (http://nd.water.usgs. gov/devilslake/data, accessed February 8, 2011), when Devils Lake began spilling through the Jerusalem Outlet into Stump Lake. Generally, since May of 1999, Devils Lake has been above the spill elevation. As a result, the water level of Stump Lake rose nearly $40 \mathrm{ft}$ in less than 10 years, until about September 2007, when the water levels of Devils Lake and Stump Lake equalized at about $1,447 \mathrm{ft}$.

In 2002, in an effort to reduce the rate of water-level rise, the State of North Dakota began construction of an outlet near Minnewaukan that diverts water into Peterson Coulee and 


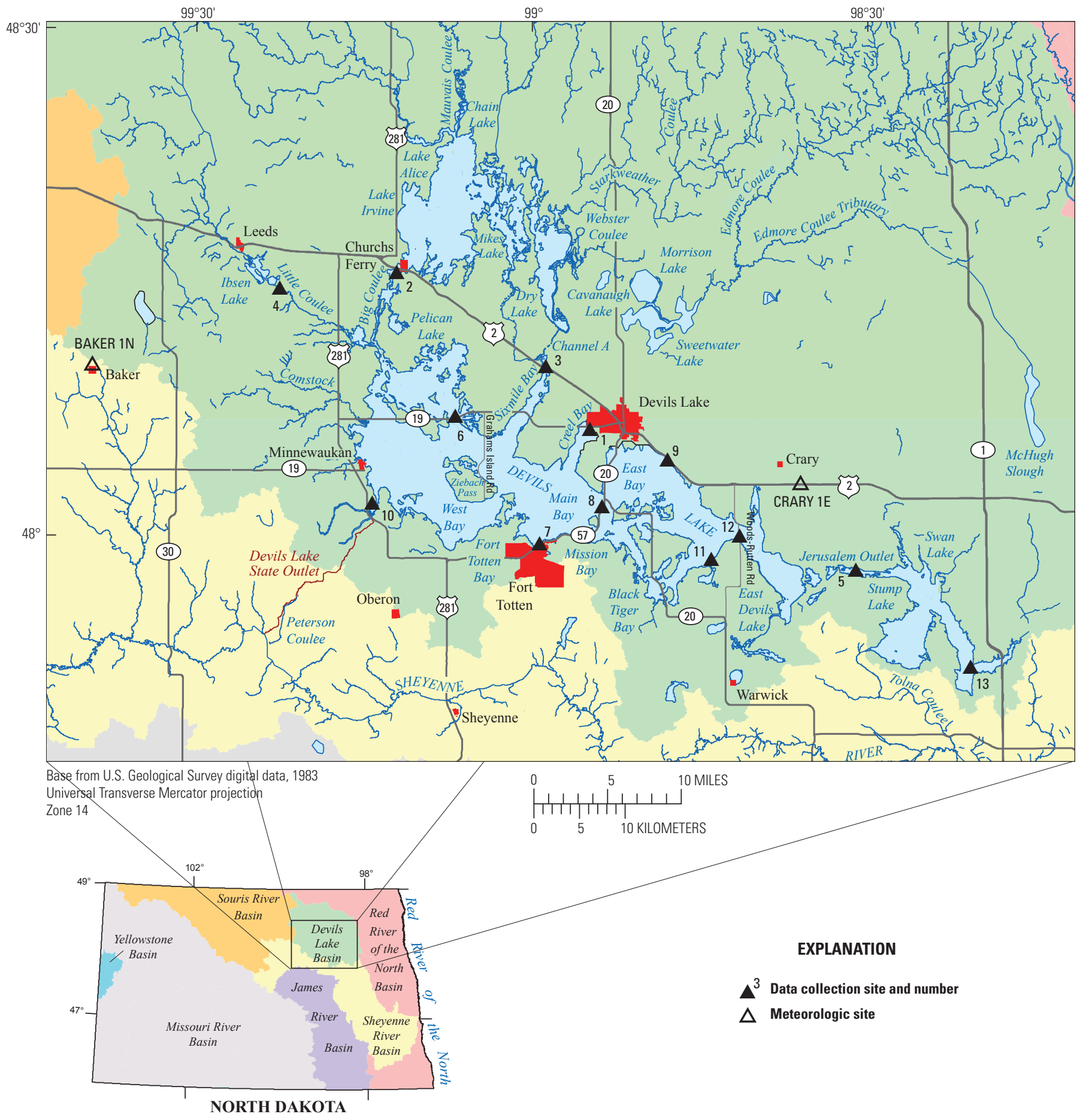

Figure 1. Location of data collection sites in Devils Lake, North Dakota, 2006. 
Figure 2. Historic water levels of Devils Lake near Devils Lake, North Dakota (U.S. Geological Survey streamflow-gaging station 05056500; http://nd.water. usgs.gov/devilslake/index.html, accessed March 14, 2011).

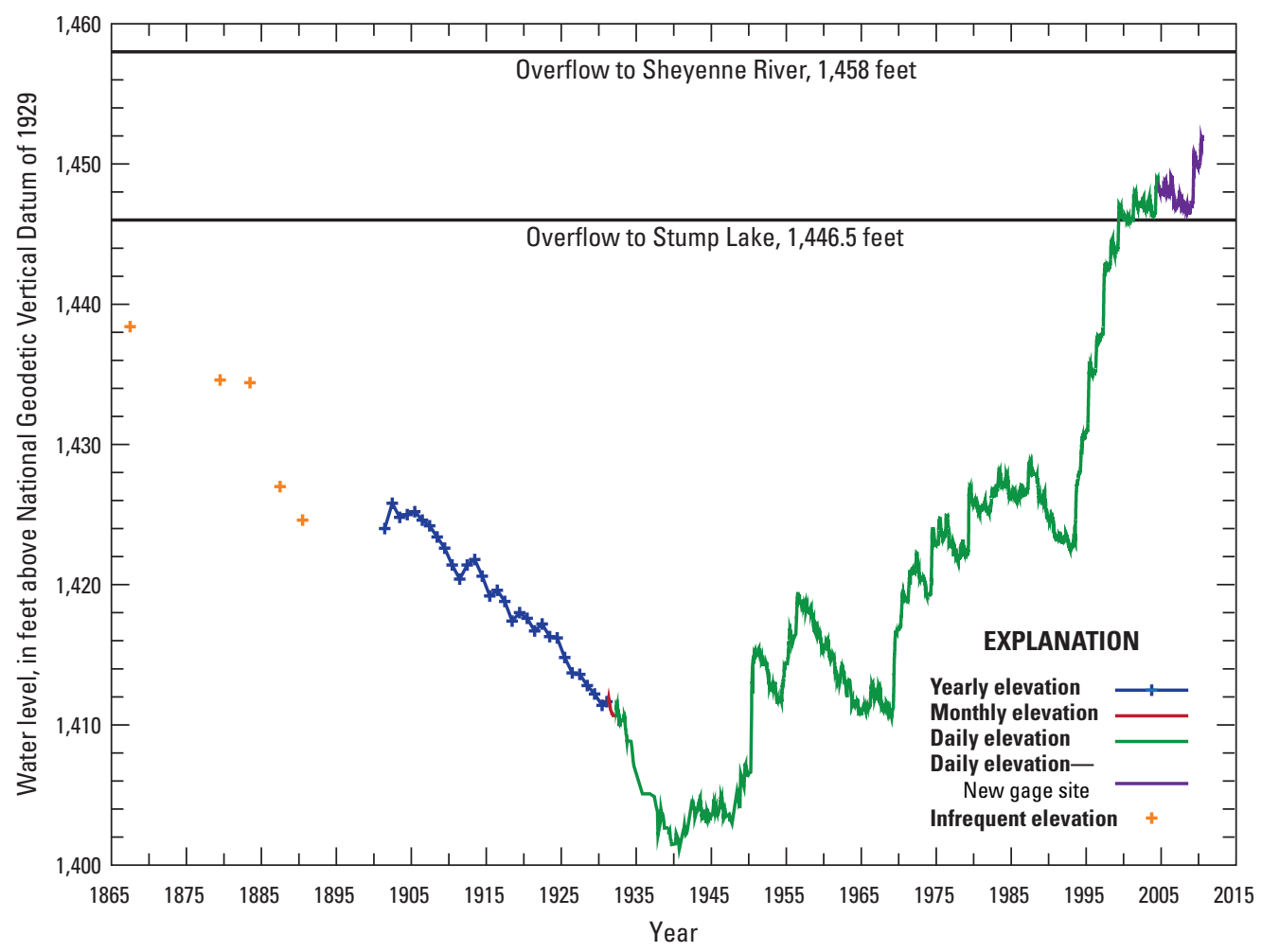

subsequently to the Sheyenne River (fig. 1). In summer 2005, construction was completed and the State of North Dakota began operation of the Devils Lake State Outlet. Initially, the outlet pumps were designed for a maximum operating capacity of 100 cubic feet per second $\left(\mathrm{ft}^{3} / \mathrm{s}\right.$ ) (North Dakota State Water Commission, 2010). Water is released from the Devils Lake State Outlet when requirements in the operating permit are met. The operating permit (http://www.swc. state.nd.us/4dlink9/4dcgi/GetSubCategoryRecord/Devils\%20 Lake\%20Flooding/Outlet, accessed August 27, 2010), which is renewed annually, restricts operation based on streamflow and sulfate concentrations in the Sheyenne River. Minimal water (460 acre-ft) was released between 2005 and 2008 because the requirements in the operating permit were not met. In 2009, the requirements of the operating permit were revised. As a result, operation requirements were met and a total of 11,000 acre-ft of water was released from the Devils Lake State Outlet from the end of May through mid-October. In 2010, modifications were made to the pumps to increase the maximum capacity of Devils Lake State Outlet to $250 \mathrm{ft}^{3} / \mathrm{s}$ (North Dakota State Water Commission, 2010).

Fluctuations in the water level of Devils Lake happen on a relatively short time scale in response to seasonal variability and on a long time scale in response to climate variability. Because of seasonal variability, water levels in any given year generally rise in the spring in response to snow melt and rain, reaching a peak water level sometime between April and July, decline through the summer months in response to evaporation reaching a minimum in late fall or early winter, and increase through the winter months mainly in response to precipitation (Wiche, 1994).
Surface-water inflow to Devils Lake occurs through three main pathways: Big Coulee, Channel A, and small ungaged tributaries (fig.1). With a drainage area of approximately 1,580 $\mathrm{mi}^{2}$ (this estimate includes the drainage area of Little Coulee), Big Coulee is the main tributary to Devils Lake, and drains the majority of the chain of lakes (Mikes Lake, Chain Lake, Lake Alice, and Lake Irvine) in the Devils Lake Basin (fig. 1). In most years, Channel A is the second largest contributor of inflow to Devils Lake and drains approximately $930 \mathrm{mi}^{2}$. Channel A was constructed in 1979 and drains the remainder of the chain of lakes (Sweetwater Lake, Morrison Lake, and Dry Lake) (fig. 1). A small quantity of runoff also enters Devils Lake by overland flow and in small tributaries from drainage areas adjacent to Devils Lake. Precipitation falling directly on the lake is another source of inflow to the lake, and depending on the year, it can be the largest contributor of inflow to Devils Lake (Wiche, 1994). Groundwater inflow is a relatively small percentage of total inflow but is relatively constant from year to year (Wiche, 1994). The only natural mechanism for removal of water from Devils Lake below 1,446.5 $\mathrm{ft}$ is evaporation. When the water level exceeds $1,446.5 \mathrm{ft}$, water is removed from Devils Lake through Jerusalem Outlet, and begins to fill Stump Lake. A small quantity of surface-water inflow enters Stump Lake through ungaged tributaries and overland flow, but inflows are small in comparison to inflows to Devils Lake (Vecchia, 2008).

On a long time scale, the water level of Devils Lake fluctuates in response to interdecadal variability. Interdecadal variability defined, generally, as the movement of the jet stream from year to year, shifts the distribution of precipitation around the globe (Wiche and others, 2000). Long-term 
shifts in circulation patterns cause long-term shifts in annual precipitation and temperature patterns. As a terminal lake, Devils Lake has an enhanced sensitivity to long-terms shifts in global circulation patterns as the water level depends on many years of antecedent precipitation, runoff, and evaporation (Wiche and others, 2000). If either precipitation and runoff, or evaporation dominates, a corresponding dramatic response occurs in the water level. A shift in the annual precipitation for the Devils Lake basin has occurred in recent years. The average precipitation for 1950-79 was about 18.3 inches (in.) per year (Vecchia, 2008). An abrupt shift occurred in about 1980 resulting in an increase in average annual precipitation to 22.4 in. for 1980-2006 (Vecchia, 2008). This increase in average annual precipitation and associated increase in runoff from the basin caused the dramatic rise in the water level of Devils Lakes and, correspondingly, Stump Lake.

\section{Previous Studies}

Numerous studies have been conducted describing the hydrology of Devils Lake and the problems associated with rising water levels. Wiche (1986) analyzed hydrologic and climatological factors affecting water levels of Devils Lake and determined that, similar to other terminal lakes, the water level of Devils Lake primarily fluctuates in response to long-term changes in precipitation. Wiche and others (2000) described how the atmospheric weather patterns from 1977 to 1999 were wetter than before 1977 and that the wet conditions in 2000, were expected to continue beyond the first decade of the century into 2015. Conditions have continued to be wet since 2000 and based on paleoclimatic evidence and recent research on climate dynamics, the conditions that began around 2007 are not likely to end anytime soon (Vecchia, 2008). There is about a 72-percent chance wet conditions will last at least 10 more years and about a 37-percent chance wet conditions will last at least 30 more years (Vecchia, 2008).

Before the present study, water-balance and statistical models have been used to simulate water levels for Devils Lake. Ryan and Wiche (1988) developed a monthly waterbalance model to simulate the elevation of Devils Lake for low-runoff conditions and high-runoff conditions. Wiche and Vecchia (1996) used two approaches, an annual lake-volume model and a statistical water mass-balance model, to estimate probabilities of future water levels. Vecchia (2002) developed a monthly water-balance model and a regression model to determine the potential effects of emergency outlet alternatives on future water levels and the water quality of Devils Lake. Vecchia (2008) updated the 2002 regression model to analyze flood risk for residents near Devils Lake. These previous modeling studies were based on water-balance and statistical probabilities, but a complete hydrodynamic model that can evaluate the effect of different inflow scenarios on water levels, circulation, and transport throughout the lake has never been completed.

\section{Methods of Data Collection}

A comprehensive data set, including water levels, water velocity, streamflow, specific conductance (SC), and water temperature (WT), was collected at 13 sites in 2006 for model development and calibration (fig. 1 and table 1). Weather data were compiled from existing weather stations located near the lake. Of the 13 data-collection sites, 9 were lake sites (sites 1 , 6-13), 3 were inflow sites (sites 2-4), and 1 was an outflow site (site 5). At six of the nine lake sites, only water-level data were collected (table 1). At the other three lake sites, water velocity, SC, and WT data were collected in addition to water levels (table 1). Streamflow was measured at all three inflow sites, and SC and WT were measured at two of the inflow sites.

\section{Water Levels}

Water levels at several locations on the lake were measured for use in comparison with simulated water levels during model calibration. Water-level data were collected according to USGS protocols (Rantz and others, 1982) using vented pressure transducers that were corrected to wire-weight gage readings at sites $1,7,9,10,11$, and 13 (fig. 1 and table 1). The elevation of the checkbar on the wire-weight gage was determined by the NDSWC using real-time kinematics (RTK) surveying equipment and state benchmark elevations. Surveying with RTK is very accurate with errors in elevation as small as plus or minus $0.04 \mathrm{ft}$ (Dan Sauter, North Dakota State Water Commission, oral commun., 2009). However, the distance between the sites and the state benchmarks were relatively large, which increased the error in elevation. Checkbar elevations were estimated to have an error of plus or minus 0.1 to $0.2 \mathrm{ft}$ (Dan Sauter, North Dakota State Water Commission, oral commun., 2009). Elevations from the NDSWC were referenced to the North American Vertical Datum of 1988 (NAVD 88), but were converted to NGVD 29 for the purposes of this report.

Using the checkbar elevation surveyed by the NDSWC, water levels for sites 1, 7, 9, 10, 11, and 13 were determined (Rantz and others, 1982). However, the error in the elevations made it difficult to compare water levels between sites. To compare water levels between sites, site 1 was used as a reference and all sites were corrected to site 1. Corrections were determined by comparing differences in daily water levels between each site and site 1 during three different time periods when winds were calm and inflows were minimal. For each site, the differences for the three periods were averaged, and corrections ranged from $0.0 \mathrm{ft}$ to $-0.25 \mathrm{ft}$. Any water levels presented hereafter will be the corrected water levels. 
Table 1. Data collection sites for Devils Lake, North Dakota, 2006.

[AVM, acoustic velocity meters. Q, streamflow; SC; specific conductance, WT, water temperature

\begin{tabular}{|c|c|c|c|c|c|}
\hline $\begin{array}{c}\text { Map } \\
\text { identification } \\
\text { number } \\
\text { (fig. 1) }\end{array}$ & $\begin{array}{l}\text { USGS Station } \\
\text { Number }\end{array}$ & Station Name & $\begin{array}{l}\text { Type of } \\
\text { gage }\end{array}$ & Equipment & Data collected \\
\hline 2 & 05056265 & $\begin{array}{l}\text { Big Coulee at Highway } 2 \text { near } \\
\text { Churchs Ferry, N. Dak. }\end{array}$ & Existing & $\begin{array}{l}\text { Side-looking AVM; } \\
\text { SC/WT probe }\end{array}$ & $\begin{array}{l}\text { Index velocity; Q; mid- } \\
\text { depth SC and WT }\end{array}$ \\
\hline 4 & 05056340 & Little Coulee near Leeds, N. Dak. & Existing & Pressure transducer & Stage, Q \\
\hline 5 & 05056636 & $\begin{array}{l}\text { Devils Lake Outlet to Stump Lake near } \\
\text { Lakota, N. Dak. }\end{array}$ & Existing & Pressure transducer & Stage, Q \\
\hline 6 & 480651099070600 & $\begin{array}{l}\text { Devils Lake at State Hwy } 19 \text { Bridge near } \\
\text { Devils Lake, N. Dak. }\end{array}$ & New & $\begin{array}{l}\text { Up-looking AVM; } \\
\text { SC/WT probe }\end{array}$ & $\begin{array}{l}\text { Velocity; bottom and } \\
\text { top SC and WT }\end{array}$ \\
\hline 9 & 480455098491100 & Devils Lake at Shelvers Grove, N. Dak. & New & Pressure transducer & Lake levels \\
\hline 10 & 480131099140600 & Round Lake nr. Minnewauken, N. Dak. & New & Pressure transducer & Lake levels \\
\hline 11 & 475802098452200 & Devils Lake at Black Tiger Bay, N. Dak. & New & Pressure transducer & Lake levels \\
\hline 12 & 480345098411300 & $\begin{array}{l}\text { Devils Lake at Woods-Rutten Road near } \\
\text { Devils Lake, N. Dak. }\end{array}$ & New & $\begin{array}{l}\text { Up-looking AVM; } \\
\text { SC/WT probe }\end{array}$ & $\begin{array}{l}\text { Velocity; bottom and } \\
\text { top SC and WT }\end{array}$ \\
\hline 13 & 05056665 & Eastern Stump Lake near Lakota, N. Dak. & Existing & Pressure transducer & Lake levels \\
\hline
\end{tabular}

\section{Inflow Velocity and Streamflow}

Velocity and streamflow data were collected at the two main inflows to Devils Lake (sites 2 and 3) for use in the Devils Lake model (fig. 1 and table 1). Side-looking acoustic velocity meters (AVMs) were installed at inflow sites 2 and 3. The velocity data from the AVM were used to compute streamflow using the index-velocity method (Morlock and others, 2002). With the index-velocity method, an area is computed from a stage-area rating and a mean channel velocity is computed from an index-velocity rating (Morlock and others, 2002). For sites 2 and 3, a stage-area rating was developed for a "standard" cross-section that was surveyed and an indexvelocity rating was developed between index velocity (the AVM measured velocity) and mean channel velocity (determined from discrete discharge measurements). Given the area in square feet from the stage-area rating, and the mean velocity in feet per second from the index-velocity rating, a discharge in cubic feet per second was computed (Morlock and others, 2002).

\section{Lake Velocity}

Three-dimensional velocity profile measurements were collected using up-looking AVMs installed at three bridge crossings over Devils Lake (sites 6, 8, and 12) (fig. 1 and table 1). Within the AVM calculations, the water column is divided vertically into uniform segments called depth cells. For each depth cell, an average velocity is estimated. AVMs have a blanking distance, or space between the face of the $\mathrm{AVM}$ and the start of the first cell; in other words, an area where velocity is not measured. At sites 6 and 12, the blanking distance was $1.5 \mathrm{ft}$ and the cell size was $2.0 \mathrm{ft}$. The depth of the water at sites 6 and 12 allowed for six cells of data to be collected. At site 8 , the blanking distance was $0.66 \mathrm{ft}$ and the cell size was $0.82 \mathrm{ft}$. Seven cells of velocity data were collected at site 8 .

Within each of the depth cells, three-dimensional velocity data were collected. The AVM can only measure the velocity of motion parallel to the acoustic path, which is called the radial velocity (Mueller and Wagner, 2009). From the radial velocity, three-dimensional velocity components can be computed for an orthogonal coordinate system. The threedimensional velocity components from the AVMs at sites 6, 8 , and 12 included velocity in the upward direction (upward velocity component), horizontal velocity along an east-west line (east-west velocity component), and horizontal velocity along a north-south line (north-south velocity component). The upward velocity component was very small and is not presented in the report. From the three velocity components, a resultant vector that represents the current speed and direction 
was computed. For the purposes of this report, depth-averaged values were used for the horizontal velocity components and the current speed and direction. At site 6, the compass calibration failed, resulting in inaccurate compass directions from the AVM. The data could not be corrected with reasonable accuracy, and as a result, data from the AVM at site 6 were not used. At site 8, on June 3, 2006, it appears that the AVM moved or tilted and eventually tipped over on June 16, 2006. As a result, data were missing from June 3 through July 7 , 2006, when divers turned the AVM back over.

\section{Specific Conductance and Water Temperature}

Continuous SC and WT were measured at sites 2, 3, 6, 8, and 12 from February 2006 (site 8) to October 2006 (sites $6,8,12$ ) (fig. 1 and table 1) using Campbell Scientific 547A conductivity and water temperature probes (http://www. campbellsci.com/documents/manuals/cs547a.pdf, accessed March 14, 2011). The probes were deployed in a permanent installation which did not allow access to the probes during the data collection period. Under these conditions, the continuous SC and WT data collected for all sites during the data-collection period are considered poor. However, the SC and WT data are valuable because they show relative changes in SC and WT with respect to location, depth, and time. The probes were installed at approximately one-half the total depth of the water column at sites 2 and 3, and, SC and WT data were collected from May through July 2006 (site 2) and May through early August 2006 (site 3). At sites 6 and 12, the probes were installed near the top and near the bottom of the water column, and SC and WT data were collected from May through mid (site 12) to late October (site 6). At site 8, four probes were installed at approximately 3 -foot intervals (starting from the bottom), and data was collected from February 2006 through mid October 2006.

\section{Meteorological Data}

Meteorological data used in the Devils Lake model included air temperature, wind speed, wind direction, relative humidity, solar radiation, precipitation, and evaporation from April through September 30, 2006, and April 1 through September 30, 2009. Meteorological data were compiled from North Dakota Agricultural Weather Network (NDAWN) stations located near Crary, ND (Crary 1E, fig.1) and Baker, ND (Baker 1N, fig.1) (http://ndawn.ndsu.nodak.edu/hourly-tableform.html, accessed August 27, 2010).

\section{Hydrologic Conditions in Devils Lake for 2006}

The hydrologic conditions for Devils Lake for 2006 are described in this section including inflows to the lake, water levels and velocities, and flows within the lake. In addition, SC and WT in Devils Lake are described.

\section{Inflows}

In 2006, the largest volume of inflow into Devils Lake occurred during April and May during spring runoff (fig. 3). In late May, following the major flush of snowmelt, Big Coulee

Figure 3. Measured inflows to Devils Lake, North Dakota and precipitation measured at the Crary $1 \mathrm{E}$ North Dakota Agricultural Weather Network station, located near Crary, North Dakota, 2006.

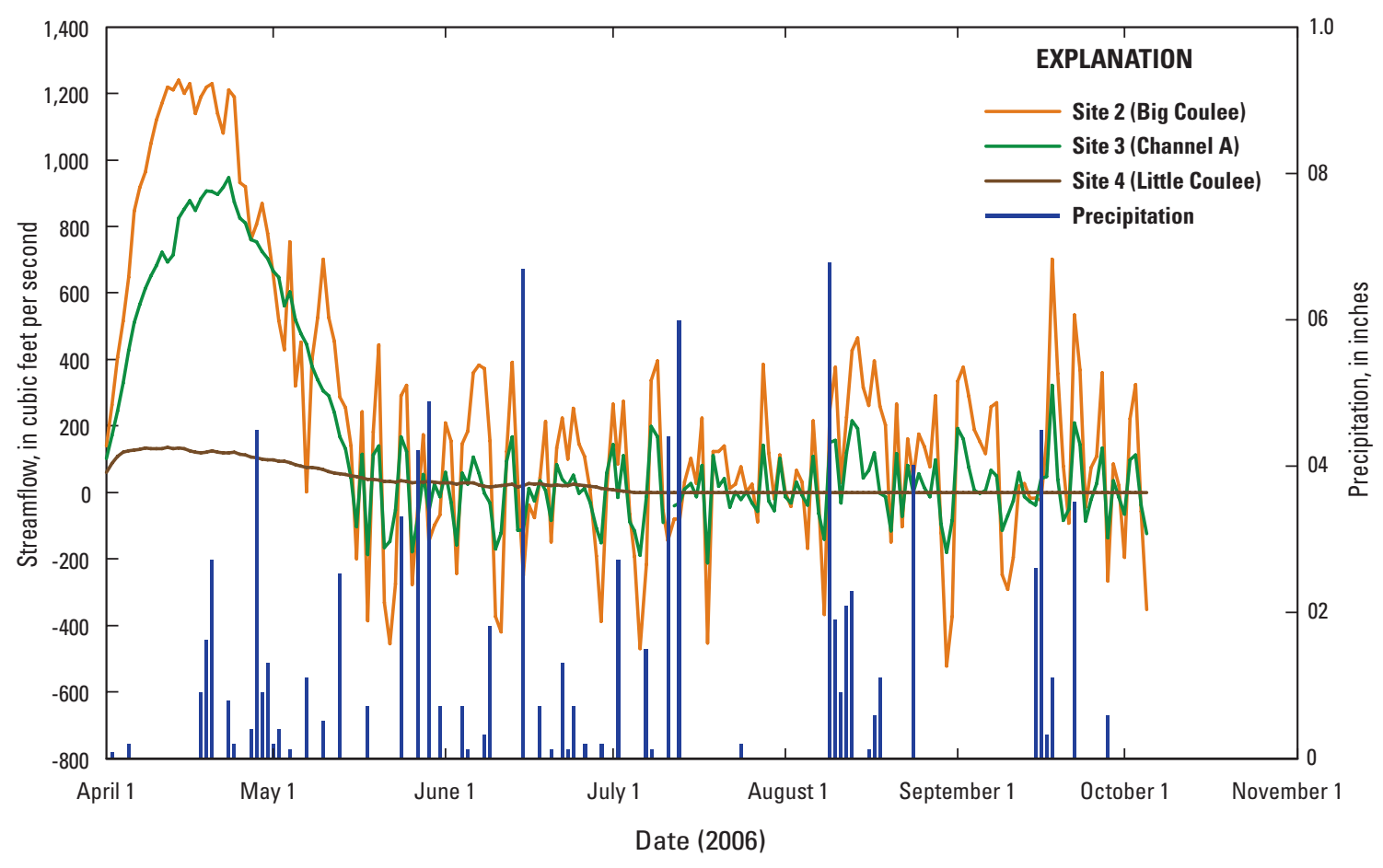


and Channel A (sites 2 and 3) began to alternate between positive and negative flows. At high water levels, like those observed in 2006, Big Coulee and Channel A are affected by backwater from Devils Lake, and under the right wind conditions, the flow direction changes. In Little Coulee, flows declined after spring runoff until flows tapered to zero in early July.

The total measured tributary inflow directly to Devils Lake from April 1 to September 30, 2006, was 157,000 acre$\mathrm{ft}$. Of the 157,000 acre-ft, Big Coulee contributed the largest amount of inflow, with a total inflow of about 90,000 acre-ft. Channel A contributed the second largest amount of inflow, 55,000 acre-ft, and Little Coulee contributed the smallest amount of inflow, about 12,000 acre-ft. The total estimated annual inflow (which includes ungaged inflows) to the entire Devils Lake Basin in 2006 was about 242,000 acre-ft, which is slightly less than the annual average of 244,000 acre-ft for 1993-2009 (Vecchia, 2008; fig. 4). The average annual inflow for 1993-2009 is considerably greater than the average annual inflow of 33,800 acre-ft for 1950-92 (Vecchia, 2008; fig. 4).

\section{Water Levels}

In 2006, water levels in Devils Lake and Stump Lake varied seasonally and were affected by wind. Water levels in Devils Lake exhibited a seasonal pattern similar to the pattern observed for inflows (fig. 5). The maximum water level at site 1 occurred in the spring on May 9, 2006, at an elevation of $1,449.20 \mathrm{ft}$, and water levels decreased 2 feet throughout the course of the summer to a level of 1,447.30 ft on September 30, 2006. Water levels on Stump Lake exhibited a different pattern as result of inflow from Devils Lake. The water level of Stump Lake increased nearly 6 feet beginning at a water level of $1438.20 \mathrm{ft}$ on April 1, 2006, and reaching a level of 1,443.95 ft on September 30, 2006 (fig. 5). Water levels increased rapidly during spring into early summer and

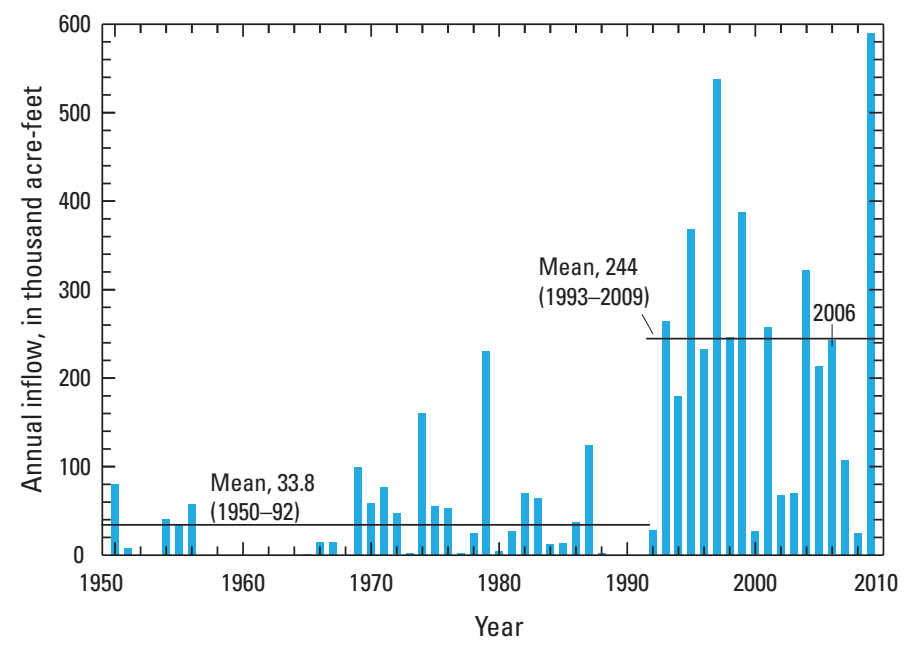

Figure 4. Estimated annual inflow to Devils Lake for 1950 through 2009.

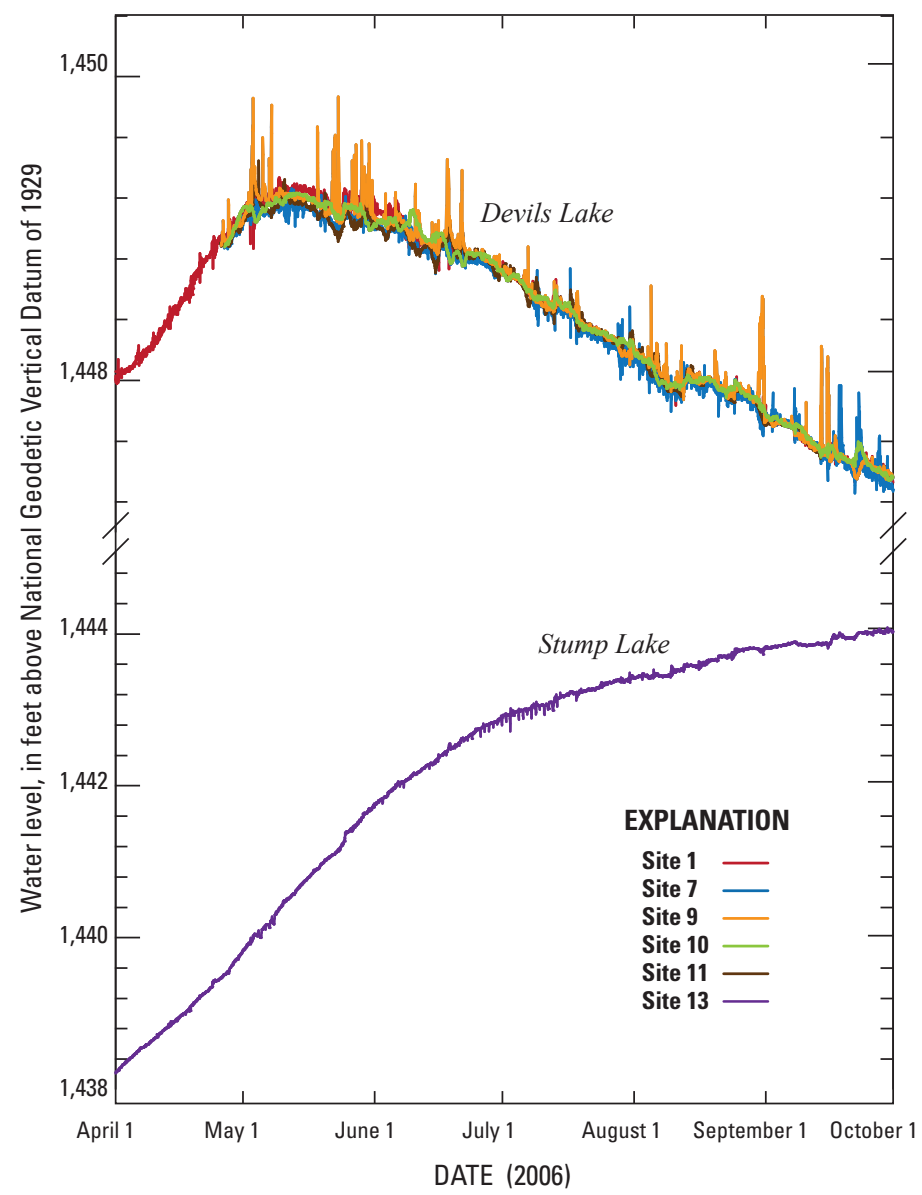

Figure 5. Hourly water levels measured at selected sites in Devils Lake and Stump Lake, North Dakota, 2006.

continued to increase during mid- to late-summer, but at a slower rate.

Water levels (fig. 5) were affected by gage location and reflect varying degrees of exposure to wind at each site and localized variability in bathymetry. Sites 10 and 11 were located in areas that were sheltered from the wind and the hourly water-level traces were relatively smooth. Site 1 was somewhat protected from the wind, but not as sheltered as sites 10 and 11, resulting in minor fluctuations in water levels. Sites 7 and 9 were located in areas that were more exposed to the wind; therefore, the hourly fluctuations in water levels at these sites were larger than at sites 10 and 11. The largest hourly fluctuations were observed at site 9 , which was located in a shallow bay that could amplify rapid wind-driven fluctuations.

At all sites on Devils Lake, the effects of the wind on water levels were noticeable. Winds in the Devils Lake Basin are strong and persistent, and the fetch across Devils Lake is nearly 25 miles at many locations. Based on 57 years of record, the prevailing wind direction in the Devils Lake area is out of the northwest and the annual average wind speed is 9.8 miles per hour (mph) (Northern Prairie Wildlife Research Center, 2010). Wind speed and direction in 2006 were close to 
long-term averages. For the period of April 1 through September 30, 2006, the prevailing wind was from the northwest and the average wind speed measured at the Crary $1 \mathrm{E}$ weather station was $9.1 \mathrm{mph}$ (http://ndawn.ndsu.nodak.edu/hourlytable-form.html, accessed August 27, 2010) (fig. 6). The maximum wind speed for April 1 through September 30, 2006, was $31.8 \mathrm{mph}$.

Data from two sites located at opposite ends of the lake during a short period of time show how water levels are affected by wind speed and direction (fig. 7). Sites 10 and site 11 are at opposite ends of the lake, and it is apparent that water levels at these two sites are out of phase with one another. When winds are strong and in an easterly direction, as they were around June 15, water levels increased at site 10, but decreased at site 11. On June 17, the wind speed increased and switched to a westerly direction, which caused water levels at site 10 to decrease, whereas water levels at site 11 increased. Depending on wind speed, wind direction, and duration of strong winds, a difference of up to about $0.25 \mathrm{ft}$ in water level occurred between the two sites.

Water levels in 2006 were some of the highest recorded. The average annual water level was 1,448.14 ft in 2006 (fig. 8).

\section{Velocities and Flows in Devils Lake}

Velocities through the bridge openings at sites 8 and 12 were typically less than 1 foot per second (ft/s), but during strong wind conditions, velocities increased and rapidly changed direction. A statistical summary of the east-west velocity component, north-south velocity component, and the current speed for both sites is presented in table 2. Positive values for the east-west velocity component and north-south velocity component represent motion of water to the east and the north, respectively. Negative values indicate motion of water in the opposite directions.

At site 8, the east-west and north-south velocity components are similar in range, which is related to the bridge opening at site 8 being oriented north-northwest to south-southeast. At site 12, the east-west velocity component was considerably higher than the north-south velocity component (table 2). The stronger east-west velocity component was related to the bridge opening at site 12 being oriented in an east-west direction (fig. 1). At site 8, the east-west and north-south velocity components are similar in range, which is related to the bridge opening at site 8 being oriented north-northwest to
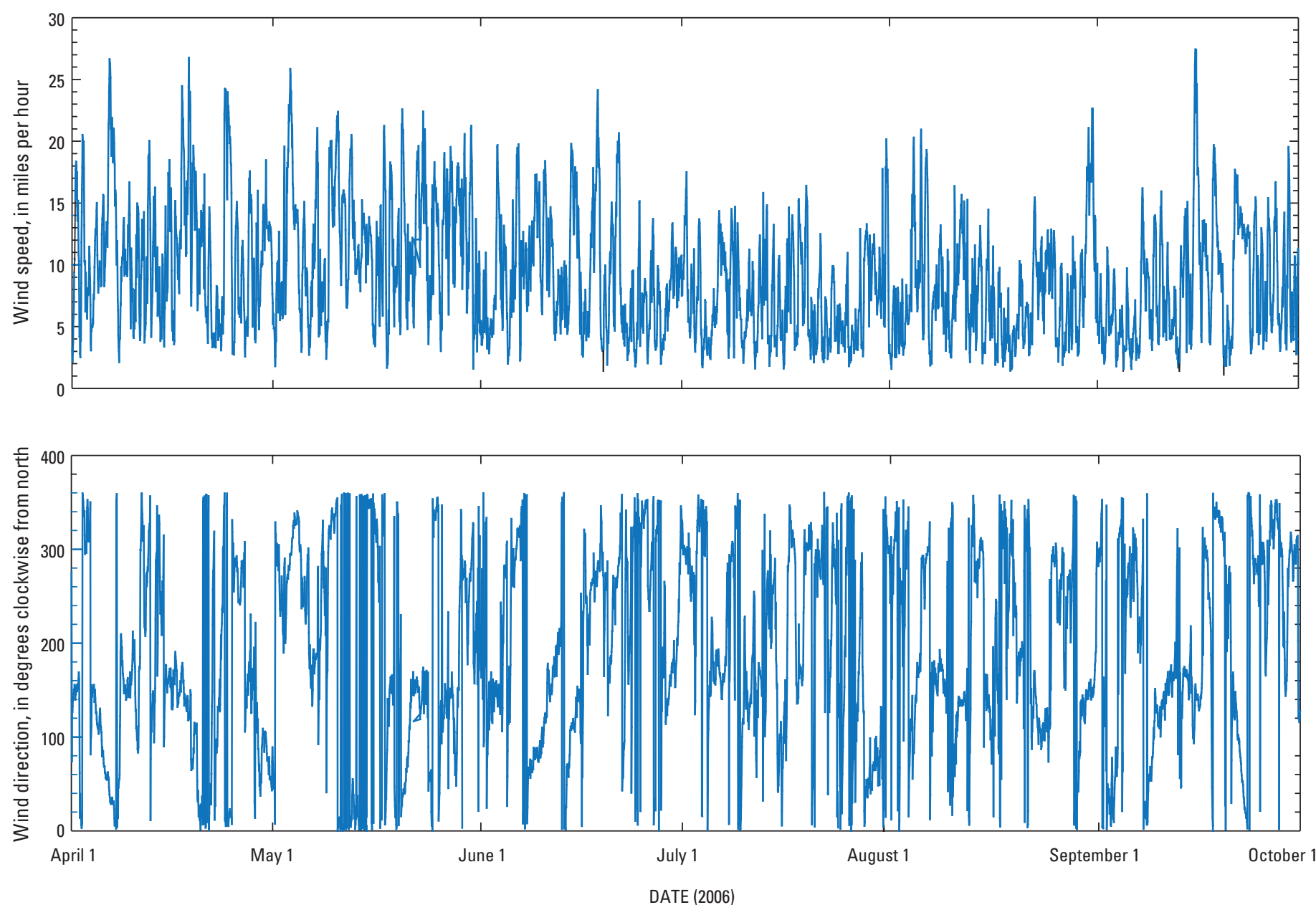

Figure 6. Wind speed and direction measured at the Crary 1E North Dakota Agricultural Weather Network weather station, located near Crary, North Dakota, April 1 through September 30, 2006. 

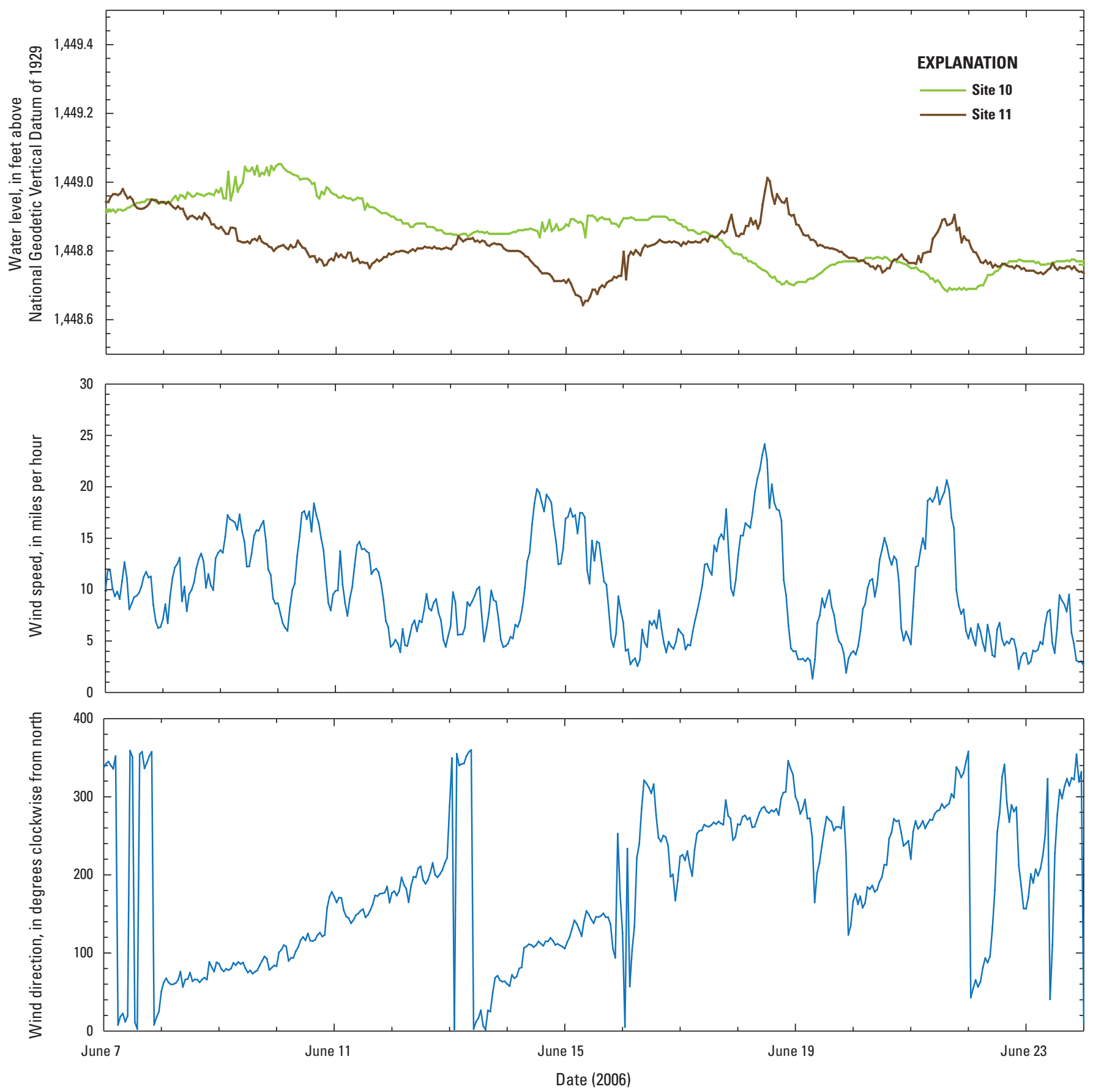

Figure 7. Water levels in Devils Lake, North Dakota at sites 10 and 11, and wind speed and direction measured at the Crary $1 \mathrm{E}$ North Dakota Agricultural Weather Network weather station, located near Crary, North Dakota from June 7 through June 23, 2006. 


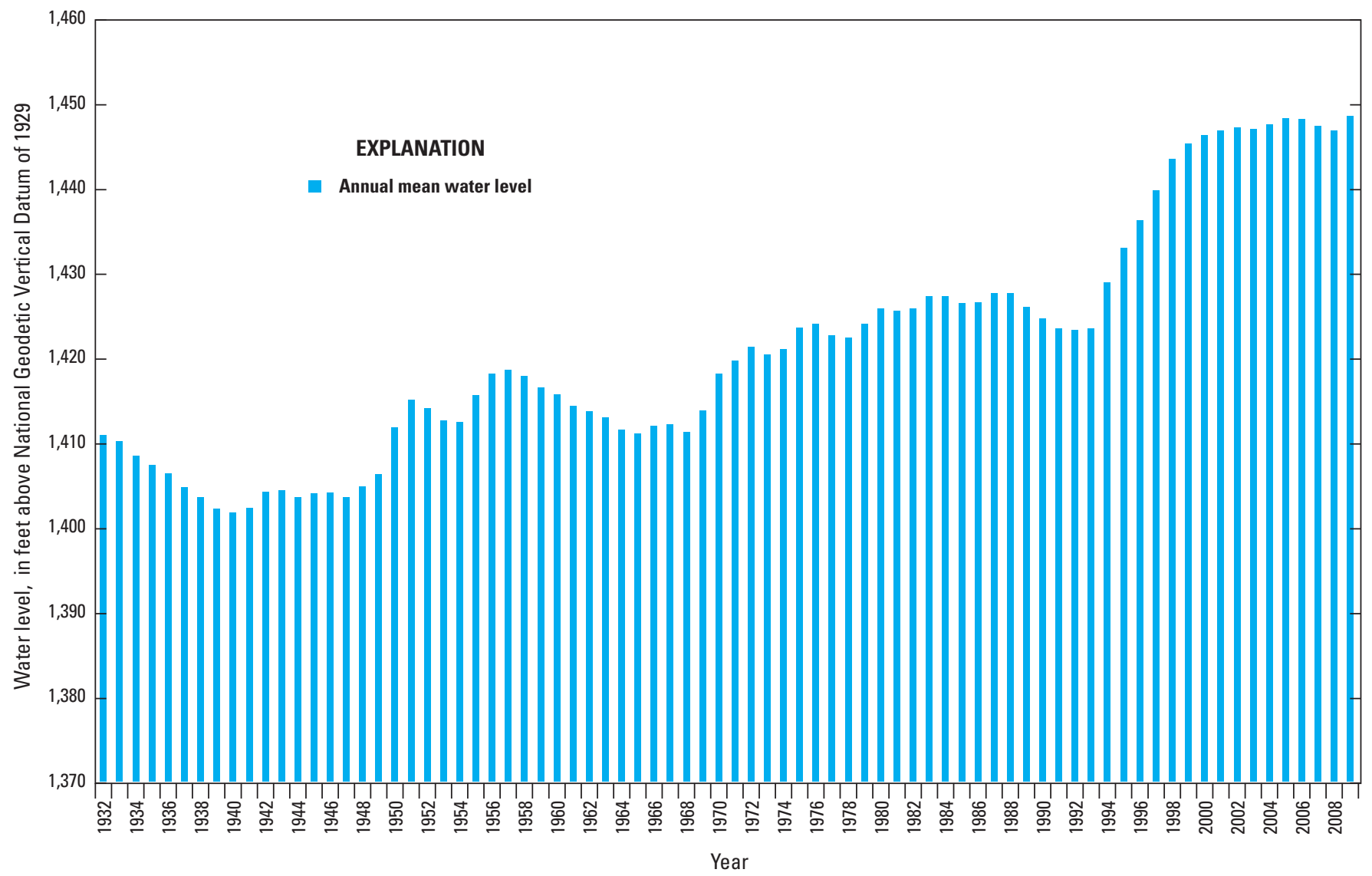

Figure 8. Average annual water level for Devils Lake, North Dakota at site 1 (USGS stream-gaging station 05056500 ) from 1932 through 2009 [Average annual water level for 2005 and 2008 were computed based on incomplete data].

Table 2. Statistical properties of select parameters from acoustic velocity meters (AVMs) located in Devils Lake, North Dakota at sites 8 and 12 .

[Multicell data were collected at both sites. Statistics are based on values averaged from: cells 1-7 for site 8, and cells 1-6 for site 12 . Positive values represent movement of water to the east (east-west velocity component) and the north (north-south velocity component). Negative values represent movement of water to the west and the south.]

\begin{tabular}{|c|c|c|c|c|c|c|c|c|c|}
\hline \multirow[t]{3}{*}{$\begin{array}{c}\text { Site } \\
\text { (fig. 1) }\end{array}$} & \multicolumn{3}{|c|}{$\begin{array}{c}\text { Depth-averaged east-west } \\
\text { velocity } \\
\text { component, } \\
\text { in feet per second }\end{array}$} & \multicolumn{3}{|c|}{$\begin{array}{l}\text { Depth-averaged north-south } \\
\text { velocity component, } \\
\text { in feet per second }\end{array}$} & \multicolumn{3}{|c|}{$\begin{array}{l}\text { Depth-averaged } \\
\text { current speed, } \\
\text { in feet per second }\end{array}$} \\
\hline & \multirow[b]{2}{*}{ Mean } & \multicolumn{2}{|c|}{ Percentile } & \multirow[b]{2}{*}{ Mean } & \multicolumn{2}{|c|}{ Percentile } & \multirow[b]{2}{*}{ Mean } & \multicolumn{2}{|c|}{ Percentile } \\
\hline & & 10 & 90 & & 10 & 90 & & 10 & 90 \\
\hline 8 & 0.09 & -0.30 & 0.50 & -0.16 & -0.90 & 0.50 & 0.50 & 0.12 & 1.06 \\
\hline
\end{tabular}


south-southeast. On average, current speed was greater at site 12 than site 8.

Wind had an effect on direction and velocity through the bridge openings, which ultimately affects flow through the bridges. A marked example of this was observed on July 11, 2006, at site 8 when five transects were made using an Acoustic Doppler Profiler (ADCP), which yielded five very different discharges (fig. 9).

Using velocities from the AVM, and the five discharge values from the ADCP, the index-velocity method was applied to compute flow through the bridge opening for a short period on July 11, 2006. This flow was then compared with wind speed that was projected onto the axis of flow through the bridge opening. Negative wind speed indicates that the wind is blowing upstream (from southeast to northwest) through the bridge opening. Wind data at 10 -minute intervals were available from a weather station located nearby on North Dakota Highway 20 (http://rwis.dot.nd.gov/scanweb/swframe.asp? Pageid $=$ RPUStatus \&Units $=$ English \& Groupid $=597000 \& S i$ teid $=597015 \&$ DisplayClass $=$ Java\&SenType $=$ All, accessed September 8, 2010). On July 11, 2006, at 15:06, the wind was blowing at $41 \mathrm{mph}$ downstream through the bridge opening. At 15:11, the wind changed to blowing upstream through the bridge opening and the speed decreased to $9 \mathrm{mph}$. A corresponding reversal of flow through the bridge occurred, with flow decreasing from $1,800 \mathrm{ft}^{3} / \mathrm{s}$ at 15:06 to $-700 \mathrm{ft}^{3} / \mathrm{s}$ at
15:11. Following the extreme reversal in flow at 15:11, the flow reverted to the downstream direction between 15:16 and 15:26 reaching nearly the same peak flow that was observed at 15:06.

\section{Specific Conductance and Water Temperature}

In 2006, continuous SC and WT data measured in Big Coulee, Channel A, and Devils Lake varied spatially and seasonally (fig. 10). The lowest SC values were observed in Big Coulee and Channel A (sites 2 and 3) and the highest SC values were observed at site 12 in Devils Lake. A gradient of lower SC to higher SC was observed from west to east in the lake (fig. 10). Within the lake, SC concentrations were lowest at the most westerly site (site 6) and highest at the most easterly site (site 12, fig. 10). Water temperatures were higher in Big Coulee and Channel A (sites 2 and 3) compared to Devils Lake in the spring, but by mid-June, WTs were similar for all sites (fig. 10).

At site 8, where four depths of temperature and SC were measured, a slight thermal stratification is evident in the late winter months (February through March) and a stronger stratification of SC is evident (fig.11). The temperature difference between top and bottom is small, with less than 0.5 degrees Celsius $\left({ }^{\circ} \mathrm{C}\right)$ difference on average (February through March). With a temperature difference of $0.5^{\circ} \mathrm{C}$ at this time of year,

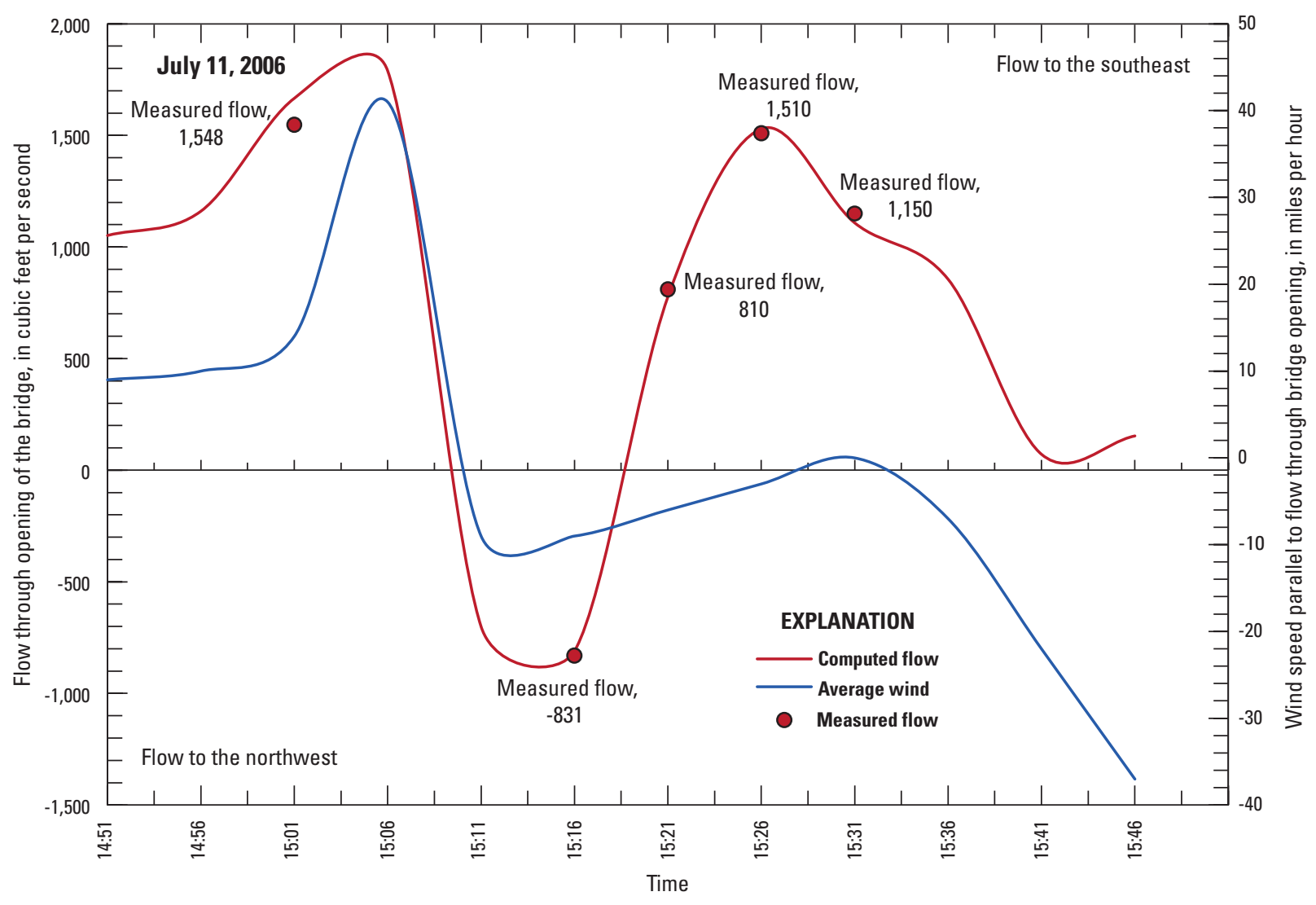

Figure 9. Effect of wind on flow through bridge opening at site 8, July 11, 2006. 

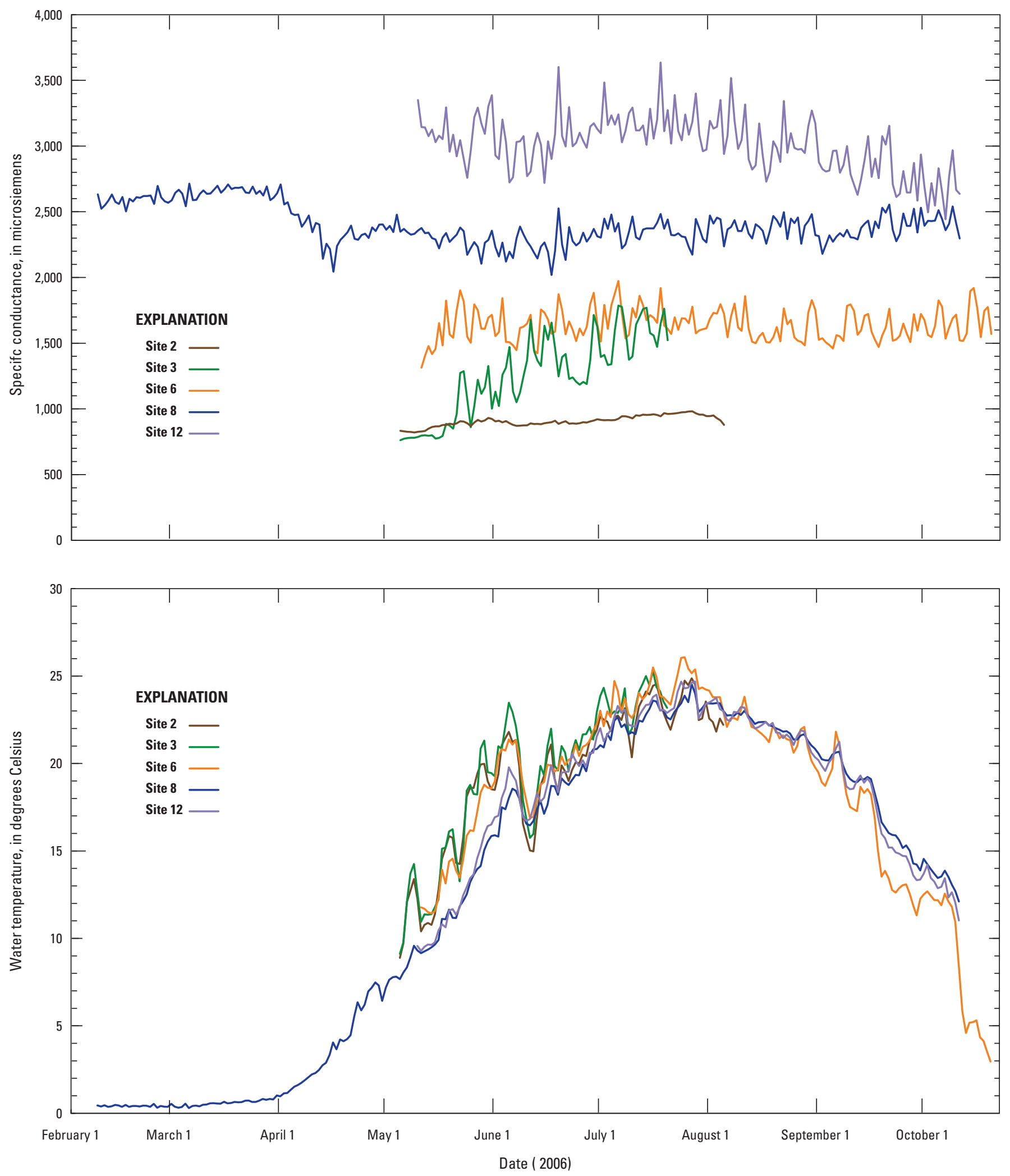

Figure 10. Continuously measured specific conductance and water temperature in Devils Lake, North Dakota, 2006. Measurements were made at mid-depth for Big Coulee (site 2) and Channel A (site 3) and measured near the water surface for sites 6, 8, and 12 in the lake. 

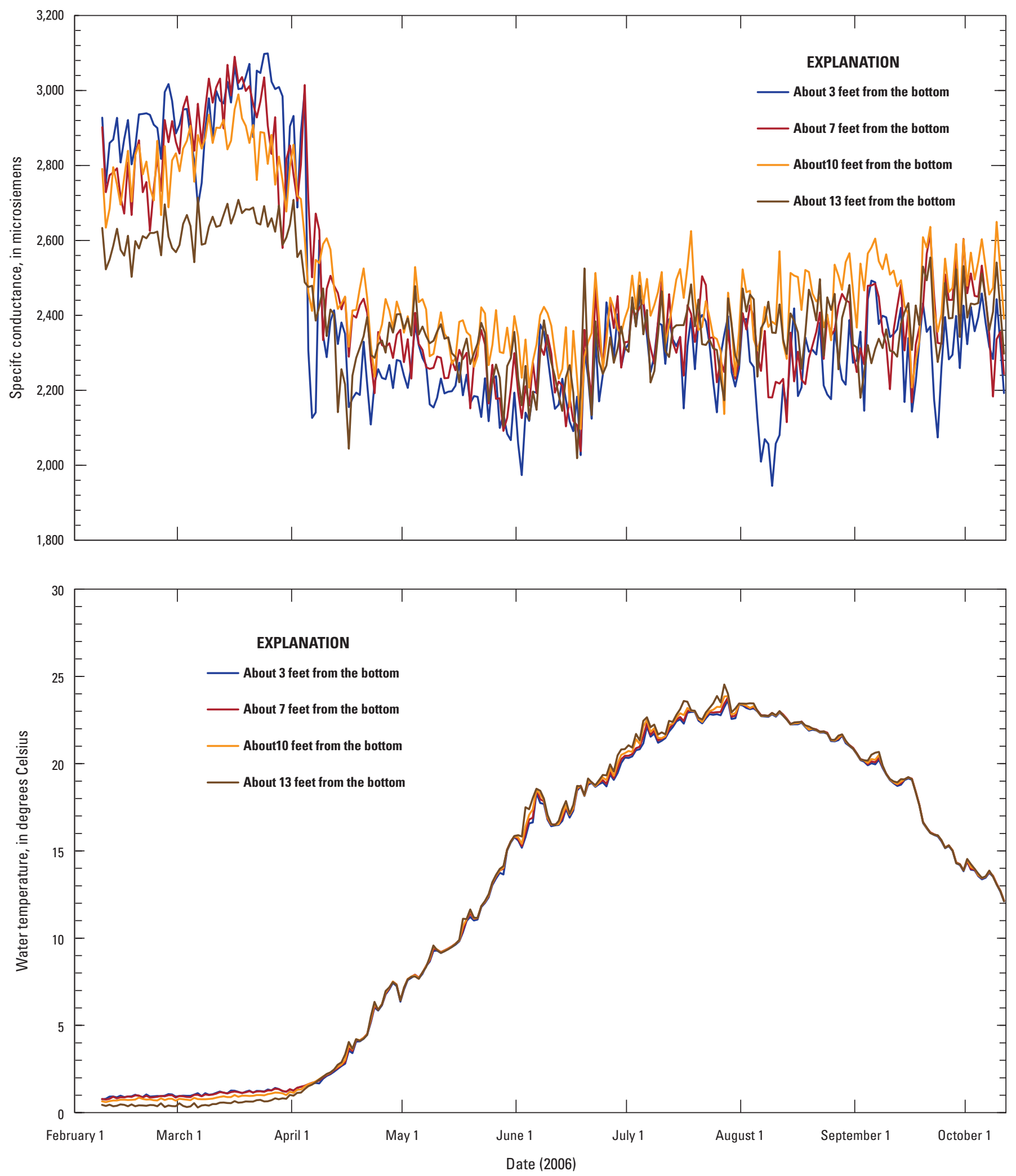

Figure 11. Specific conductance and water temperature measured at four depths at site 8 in Devils Lake, North Dakota, 2006. 
density $(\rho)$ computed as a function of temperature only, differs only by 0.03 kilograms per cubic meter $\left(\mathrm{kg} \mathrm{m}^{-3}\right)$ between the top and bottom (Gill, 1982). However, if the average $\rho$ (February through March) is computed as a function of temperature and SC concentration (Gill, 1982; Hill and others, 1986), the difference in $\rho$ between top and bottom is about $0.13 \mathrm{~kg} \mathrm{~m}^{-3}$. The higher SC concentration near the lake bed is most likely because of diffusion of solids from the lake bed into the water column. Diffusion of dissolved solids from the lake bed into the water column has been documented for Devils Lake (Komor, 1994; Lent, 1994). Around April 4, turnover occurred causing the lake to mix. This phenomenon is evidenced by the lack of stratification in the WT and SC (fig. 11). Following turnover, WT and SC were relatively uniform at site 8 , most likely because of wind-driven mixing in the bridge opening.

\section{Two-Dimensional Hydrodynamic Model Development, Calibration, and Application}

The numerical model, UnTRIM, was applied to Devils Lake, North Dakota. UnTRIM is a three-dimensional hydrodynamic model that runs on an unstructured orthogonal grid. For the Devils Lake application, it was used with only one vertical computational layer, and therefore reverts to the two-dimensional case. Within the computational core of the UnTRIM model, the governing equations for three-dimensional, baroclinic circulation and transport of scalar variables are solved using a semi-implicit, finite-difference method (Casulli and Cheng, 1992; Casulli and Cattani, 1994). The governing equations solved in the UnTRIM model include: the conservation of mass momentum, a kinematic free-surface equation, an equation of state relating density to temperature, and a conservation equation for each scalar variable. The semi-implicit, finite-difference method efficiently solves the governing system of equations and is computationally and unconditionally stable. The UnTRIM model solves the unsteady (time-varying) shallow-water equations on a boundary fitted unstructured orthogonal grid (Casulli and Walters, 2000). The computational scheme used in UnTRIM is based on the method first proposed by Casulli (1990) for two-dimensional hydrodynamic equations, and later extended to three-dimensional equations. The wetting and drying of computational cells is simulated. The UnTRIM model has been applied in a variety of waterbodies, successfully tested for extreme hydraulic conditions, and has been extensively applied to San Francisco Bay (Cheng and others, 1993) in the two-dimensional and three-dimensional form. More recently, the UnTRIM model has been applied in three dimensions to Upper Klamath Lake, Oregon, to simulate hydrodynamics and heat transport (Wood and others, 2008) and in two dimensions to study the transport of larval suckers (Wood, 2009).

\section{Model Development}

To develop the UnTRIM model for the Devils Lake application, an unstructured orthogonal grid was constructed from available bathymetry and LiDAR (Light Detection and Ranging) data, and inputs to the model grid were specified. Also, site-specific parameters in the model were estimated for the Devils Lake application.

\section{Model Grid}

For the Devils Lake model, an unstructured orthogonal grid for all of Devils Lake, part of the chain of lakes, and Stump Lake was developed below the shoreline elevation of $1,463.8 \mathrm{ft}$ (fig. 1 and fig. 12). Big Coulee (site 2) upstream from the gaging station, and Channel A (site 3) upstream from the gaging station (fig. 1) also were included. Little Coulee inflow measured at site 4 was applied at the confluence of Big Coulee and Little Coulee (fig. 1).

Bathymetry data from the NDSWC were used to construct the model grid for portions of Devils Lake that are typically inundated. For areas around the lake that are not normally inundated, LiDAR data were available from the USACE through the Federal Emergency Management Agency (Keith LeClaire, U.S. Army Corps of Engineers, written commun., 2006). Ten-meter Digital Elevation Model (DEM) data were available from the North Dakota Game and Fish Department (http://web.apps.state.nd.us/imf/imf.jsp? site $=N D G F G e n I n f o$, accessed October 21, 2009) and were used to construct the grid for Stump Lake. It was assumed that two major highways crossing Devils Lake, ND State Highway 19 (fig. 12), and ND State Highway 57 (fig. 12) and County Road 4, also known as Woods-Rutten Road (fig.12), would continue to be maintained as the lake rises. The bridge openings for these three roadways (sites, 6, 8, and 12) were defined in the Devils Lake model at an elevation of 1,463.8 ft. For calibration and model performance testing, Graham's Island Road was represented in the model grid at an elevation of 1,463.8 ft. For the extreme flooding scenario, Graham's Island Road was not represented in the model grid.

JANET software (Lippert and Sellerhoff, 2006) was used to create and optimize the unstructured orthogonal model grid. Shoreline, bathymetry data, and DEM data were imported into the JANET software. Within JANET, the shoreline was smoothed, the grid mesh was coarsened, and individual polygons were adjusted to meet a prescribed tolerance for orthogonality. The resulting grid for the Devils Lake model is relatively large with 32,752 polygons and 18,400 vertices (fig. 12).

The model grid was separated into two areas for initializing water levels for a given simulation. The area in the model grid to the west of site 5 was initialized to the water level at site 1 , and the area east of site 5 in the model grid was initialized to the water level at site 13 (fig. 12). Inflows, outflows, and net evaporation were defined as point sources to the model grid. Net evaporation and wind were applied uniformly over 


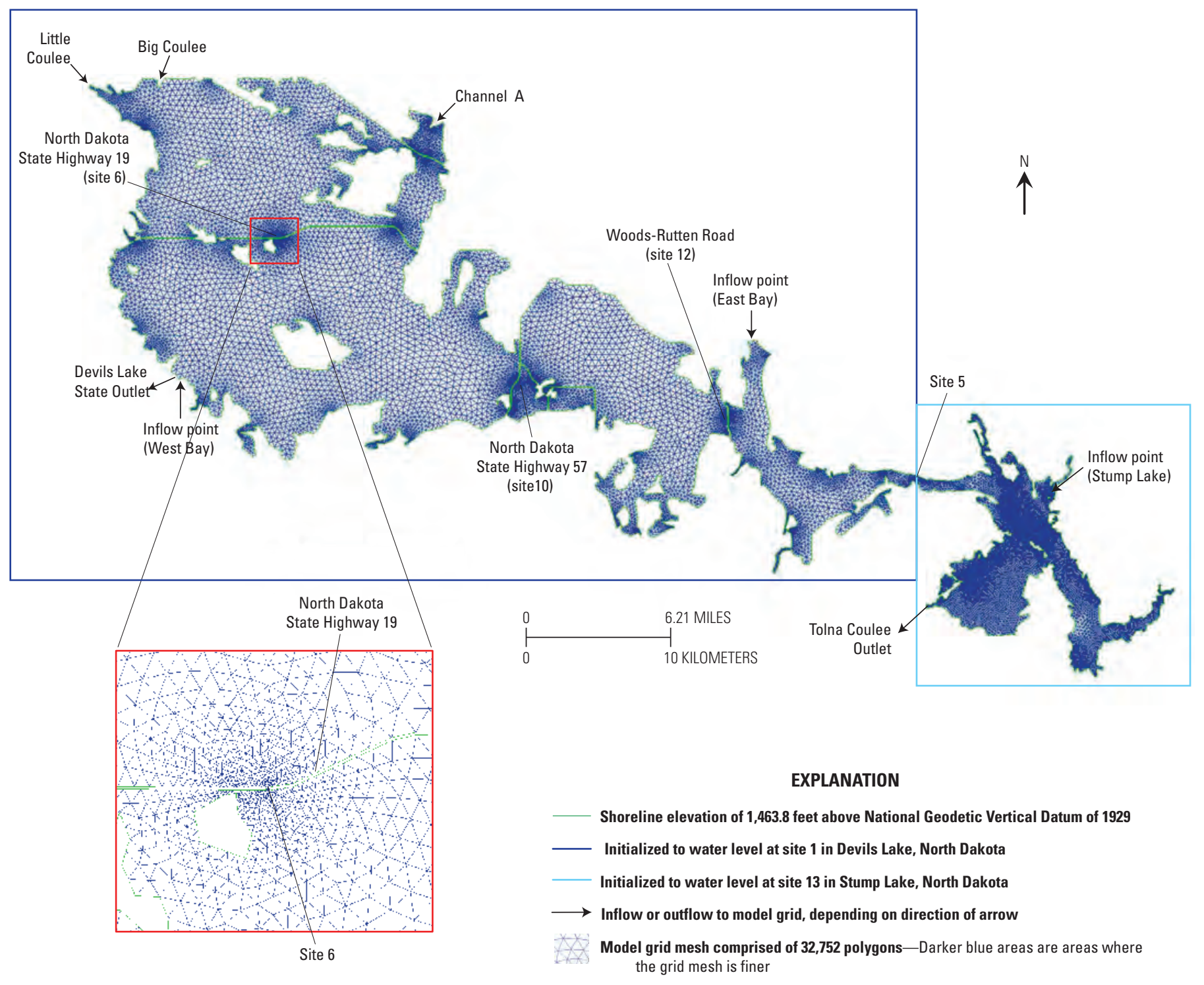

Figure 12. Unstructured orthogonal model grid of the Devils Lake model showing inflow and outflow locations, close up view of bridge opening at State Highway 19 (site 6), and areas used for initialization of water levels.

the model grid. Inflows for Big Coulee, Channel A, Little Coulee, and inflow points to East Bay, West Bay and Stump Lake were included in the model grid (fig. 12). Although six point sources to the lake were defined, some point sources were set to zero for certain simulations. Two outflow locations were defined in the model grid to represent Devils Lake State Outlet and Tolna Coulee Outlet (fig. 12). Groundwater contribution is considered to be small in comparison to other inflows and was not included. Precipitation and evapotranspiration were combined as one term, net evaporation. Net evaporation was computed as

$$
N E(t)=P(t)-M[E(t)]
$$

where
$N E(t) \quad$ is net daily evaporation, in inches
$P(t) \quad$ is daily precipitation, in inches
$M>0 \quad$ multiplier (Vecchia, 2008) adjusted during calibration; and
$E(t) \quad$ is daily potential evapotranspiration, in inches

An average of the daily precipitation data and evapotranspiration data measured at the Crary $1 \mathrm{E}$ and Baker $1 \mathrm{~N}$ weather stations was used in equation 1 (fig. 1). Potential evapotranspiration data from the weather stations were calculated with the Penman equation (http://ndawn.ndsu.nodak.edu/hourly-tableform.html, accessed August 27, 2010). Once $N E(t)$ was computed, it was applied uniformly over the model grid as a point source (if $P(t)>M[E(t)]$ ) or sink (if $P(t)<M[E(t)]$ ) as follows. The model grid was divided up evenly into point sources or sinks at 1.24-mi intervals both east-west and north-south, 
over the entire model grid, resulting in approximately 195 evenly spaced point sources. At each computational time step, $N E(t)$ was multiplied by the surface area of the model grid to get a flow rate. At each computational time step, the flow rate was then divided by the number of point sources (195) and the same amount of flow was removed or added to each point source location. Hourly wind speed and direction from the Crary $1 \mathrm{E}$ weather station were applied uniformly over the model grid.

\section{Model Parameters}

Two site-specific model parameters needed to be specified for the Devils Lake model. First, Manning's roughness coefficient $n$ was used in the bottom friction formulation and the value for Manning's $n$ was determined through calibration. Second, the surface drag coefficient, $\mathrm{C}_{10}$ was used in the surface friction formulation and was determined through calibration.

To simulate the transport of dissolved solids, the following equation of state for $\rho$ in kilogram per cubic meter as a function of water temperature $(T)$ in degrees Celsius and practical salinity $(S)$ in practical salinity units at one standard atmosphere of pressure ( $P=0$ bars) was used (Gill, 1982):

$$
\begin{gathered}
\rho(S, T, 0)=999.842594+6.793952 \times 10^{-2} \times T-9.095290 \times \\
10^{-3} \times T^{2}+1.001685 \times 10^{-4} \times T^{3}-1.120083 \times 10^{-6} \times T^{4}+ \\
6.536332 \times 10^{-9} \times T^{5}+8.24493 \times 10^{-1} \times S-4.0899 \times 10^{-3} \times T \times \\
S+7.6438 \times 10^{-5} \times T^{2} \times S-8.2467 \times 10^{-7} \times T^{3} \times S+5.3875 \times \\
10^{-9} \times T^{4} \times S-5.72466 \times 10^{-3} \times S^{3 / 2}+1.0227 \times 10^{-4} \times T \times S^{3 / 2}- \\
1.6546 \times 10^{-6} \times T^{2} \times S^{3 / 2}+4.8314 \times 10^{-4} \times S^{2} .
\end{gathered}
$$

Because SC data for Devils Lake and Stump Lake were more abundant than dissolved solids data, $\mathrm{SC}$ was used in simulating the transport of dissolved solids. SC was related to $\mathrm{S}$ according to the following set of equations by Hill and others (1986):

$$
\begin{gathered}
S=\sum_{i=0}^{5}\left(a_{i}+8.606 b_{i}\right) R_{t}{ }^{i / 2}-\left[a_{i} /\left(1+1.5 \mathrm{x}+x^{2}\right)\right]- \\
{\left[8.606 b_{i} /\left(1+y^{1 / 2}+y+y^{3 / 2}\right)\right]} \\
R_{t}=(S C / 1,000) / 53.7939 \\
x=400 R_{t} \\
y=100 R_{t}
\end{gathered}
$$

where

$$
\begin{aligned}
& a_{i} \quad \text { is a constant defined as } a_{0}=0.0080, a_{1}= \\
& \quad-0.1692, a_{2}=25.3851, a_{3}=14.0941, a_{4}= \\
& \quad-7.0261, a_{5}=2.7081 ; \\
& b_{i} \quad \text { is a constant defined as } b_{0}=0.0005, b_{1}=
\end{aligned}
$$

$$
\begin{aligned}
& \quad-0.0056, b_{2}=-0.0066, b_{3}=-0.0375, b_{4}= \\
& 0.0636, b_{5}=-0.0144 ; \\
& R_{t} \quad \text { is the ratio between measured SC in } \\
& \text { microsiemens per centimeter } \left.(\mu \mathrm{S} \mathrm{cm})^{-1}\right) \\
& \text { and the standard sea water conductivity } \\
& \text { at constant temperature of } 25^{\circ} \mathrm{C} \text { and } P=0 \\
& \text { bars }(53.7939) .
\end{aligned}
$$

\section{Model Calibration}

The Devils Lake model was calibrated using data collected from April 1 through September 30, 2006. For the 2006 calibration, water levels were initialized for Devils Lake and Stump Lake to daily water levels measured on April 1 at site $1(1,448.0 \mathrm{ft})$ and site $13(1,438.2 \mathrm{ft})$, respectively. Hourly streamflow measured at sites 2, 3, and 4 were specified as inflows to the lake for Big Coulee, Channel A, and Little Coulee, respectively. Based on Vecchia (2002), 17 percent of the gaged inflow was added to Big Coulee, Channel A, and Little Coulee to account for ungaged inflows to Devils Lake. To account for ungaged inflows to Stump Lake, 4.6 percent of the total measured inflow (Big Coulee, Channel A, and Little Coulee) was added to the inflow point on Stump Lake (Vecchia, 2008, fig.12). Ungaged inflows were added only to positive inflows. No flow was removed through the Devils Lake State Outlet because no pumping occurred in 2006.

Because the Devils Lake model was to be used for simulating the maximum water level at site 1 for an extreme flood, particular emphasis was placed on accurately simulating water levels in Devils Lake. As a measure of how accurately water levels were simulated, two statistics were used: mean error (ME) and root mean square error (RMSE). ME was calculated as the mean of the measured values minus the simulated values and is provided as a measure of the overall bias of the simulation at each site. RMSE is a measure of the overall goodness-of-fit of the simulated values to the measured values and, because it is in the same units as the quantity being simulated, it represents the error around individual simulated values. Calibration was achieved by adjusting net daily evaporation, Manning's $n$ in the bottom friction formulation, and $C_{10}$ in the surface friction formulation.

$N E(t)$ was adjusted by correcting $E(t)$ through the use a daily multiplier, $M$. An initial value for $M$ was assigned at the middle of each month (from table 2 in Vecchia, 2008) and daily values were then assigned by linearly interpolating between the middle of the month values. This process of adjusting the middle of the month values of $M$ and linearly interpolating in between was continued until the average difference between measured water levels and computed daily water levels from a simple mass balance was small $(0.10 \mathrm{ft})$. Final values of $M$ for the middle of each month are presented in table 3 . Before applying $M$, the total potential evapotranspiration, as an average of the Crary $1 \mathrm{E}$ and Baker $1 \mathrm{~N}$ weather stations, from April 1 through September 30, 2006 was 43.2 in. After applying $M$, the total evapotranspiration from 
Table 3. Mid-month multiplier applied to potential evapotranspiration data.

\begin{tabular}{lc}
\hline Month & $\begin{array}{c}\text { Multiplier for potential } \\
\text { evapotranspiration }\end{array}$ \\
\hline April & 0.13 \\
May & .262 \\
June & .498 \\
July & .669 \\
August & .851 \\
September & 1.0 \\
October & 1.0 \\
\hline
\end{tabular}

April 1 through September 30, 2006, was reduced to 24.8 in. In comparison, Farnsworth and others (1982) estimated the mean free water evaporation between May and October for Devils Lake to be about 27 in. Given the adjusted evapotranspiration (24.8 in.) and the measured precipitation (8.5 in.), $N E(t)$ for the period of April 1 through September 30, 2006, was -16.3 in.

Once the values for $M$ were determined, the Manning's $n$ value was adjusted until the simulated rise during the spring for Stump Lake was comparable to the measured spring rise. By simulating the rate of rise on Stump Lake correctly, the rate of water transfer between Devils Lake and Stump Lake will be accurate which, in turn, allows for accurate simulation of the maximum water level at site 1 under the extreme flooding scenario. An initial value of 0.03 was used for Manning's $n$ and adjusted until a final value of 0.04 was determined to be the best fit. A Manning's $n$ of 0.04 is consistent with a natural channel that has some pools and shoals (Chow, 1959), which describes the Jerusalem Outlet, the channel connecting the two lakes.

Finally, a value for $C_{10}$, the surface drag coefficient, was used in the surface friction formulation and was determined through calibration. The surface friction formulation within UnTRIM is a function of air density, wind speed and direction, and $C_{10}$ (Casulli and Lang, 2004). Typically, $C_{10}$ varies as a function of wind speed, but for this application, a constant value was used. The following formula can be used to compute $C_{10}(\mathrm{Wu}, 1969)$ :

$$
C_{10}=0.0005\left(U_{10} / 2.2369\right)^{0.5}
$$

where

$C_{10} \quad$ is the surface drag coefficient, and

$U_{10}$ is the wind speed in mph at $33 \mathrm{ft}(10 \mathrm{~m})$

above the water surface.

Different values for $\mathrm{C}_{10}$ were tested, but the effect on simulated water levels was minimal. A value of $1.04 \times 10^{-3}$ for $\mathrm{C}_{10}$ was used, approximately the value obtained when the long-term average wind speed of $U_{10}=9.8 \mathrm{mph}$ for the Devils Lake area, is substituted into equation 6.
Simulated and measured water levels were compared at sites 1, 7, 9, 10, and 11 in Devils Lake and site 13 in Stump Lake for the 2006 calibration and water level goodness-of-fitstatistics were calculated for the same sites (fig. 13, table 4). For the 2006 calibration, simulated water levels compared well with measured water levels for all sites in Devils Lake. Other than site 7, MEs for the Devils Lake sites were small and positive (table 4), indicating that simulated water levels were slightly under predicted. Simulated water levels for site $1 \mathrm{had}$ an ME of $0.02 \mathrm{ft}$ and a RMSE of $0.06 \mathrm{ft}$ (table 4). The simulated maximum water level at site 1 was within $0.13 \mathrm{ft}$ of the measured maximum water level (table 4). For all Devils Lake sites, the RMSE was within $0.10 \mathrm{ft}$. For Stump Lake (site 13), the simulated water levels were under predicted by about $0.34 \mathrm{ft}$, on average. The under prediction of water levels for Stump Lake may be caused by an underestimate of ungaged inflows to Stump Lake. Although the simulated water levels were under predicted, the simulated rate of rise during the spring compares well with the measured rate of rise (fig. 13). By correctly simulating the rate of rise on Stump Lake, the rate of water transfer between Devils Lake and Stump Lake is nearly correct, which resulted in the simulated maximum water level for site 1 to be within $0.13 \mathrm{ft}$ of the maximum measured water level. Accurate simulation of the maximum water level at site 1 in the calibration gives reasonable confidence that the Devils Lake model is able to simulate accurately the maximum water level at site 1 for the extreme flooding scenario.

The timing and direction of wind-driven fluctuations in water levels on a short time scale (a few hours to a day; fig. 7) were reproduced well by the Devils Lake model (fig. 14). For site 1 , simulated water levels follow closely the wind-driven fluctuations observed in the measured water levels (fig. 14). Consistent with measured water levels, the simulated water levels for sites 10 and 11 are out of phase with one another (fig. 14). The magnitude of the simulated fluctuations at sites 7 and 9 (fig. 13) was smaller than measured fluctuations, perhaps because localized variability in the wind was not captured by the uniform wind forcing that was applied to the Devils Lake model, or because localized bottom bathymetry was not described correctly by the model grid.

Simulated current speed was compared with measured current speed through the bridge openings at sites 8 and 12 (figs. 15 and 16; table 5). In general, simulated current speed for both sites followed the same patterns as measured current speed, but on average, simulated current speed was less than measured current speed as indicated by the positive $\mathrm{ME}$ for both sites (fig. 15 and 16; table 5). At site 12, a larger bias towards under prediction of simulated current speeds (ME of $0.32 \mathrm{ft} / \mathrm{s})$ than at site $8(\mathrm{ME}$ of $0.20 \mathrm{ft} / \mathrm{s})$ was observed (table 5). For both sites, the simulated direction of current speed was rotated slightly to the east of measured values, although the rotation was larger for site 12 (fig. 15 and 16). Simulated current speed likely was affected by the model grid configuration of the bridge openings not being identical to the physical configuration of the bridge openings. For instance, 

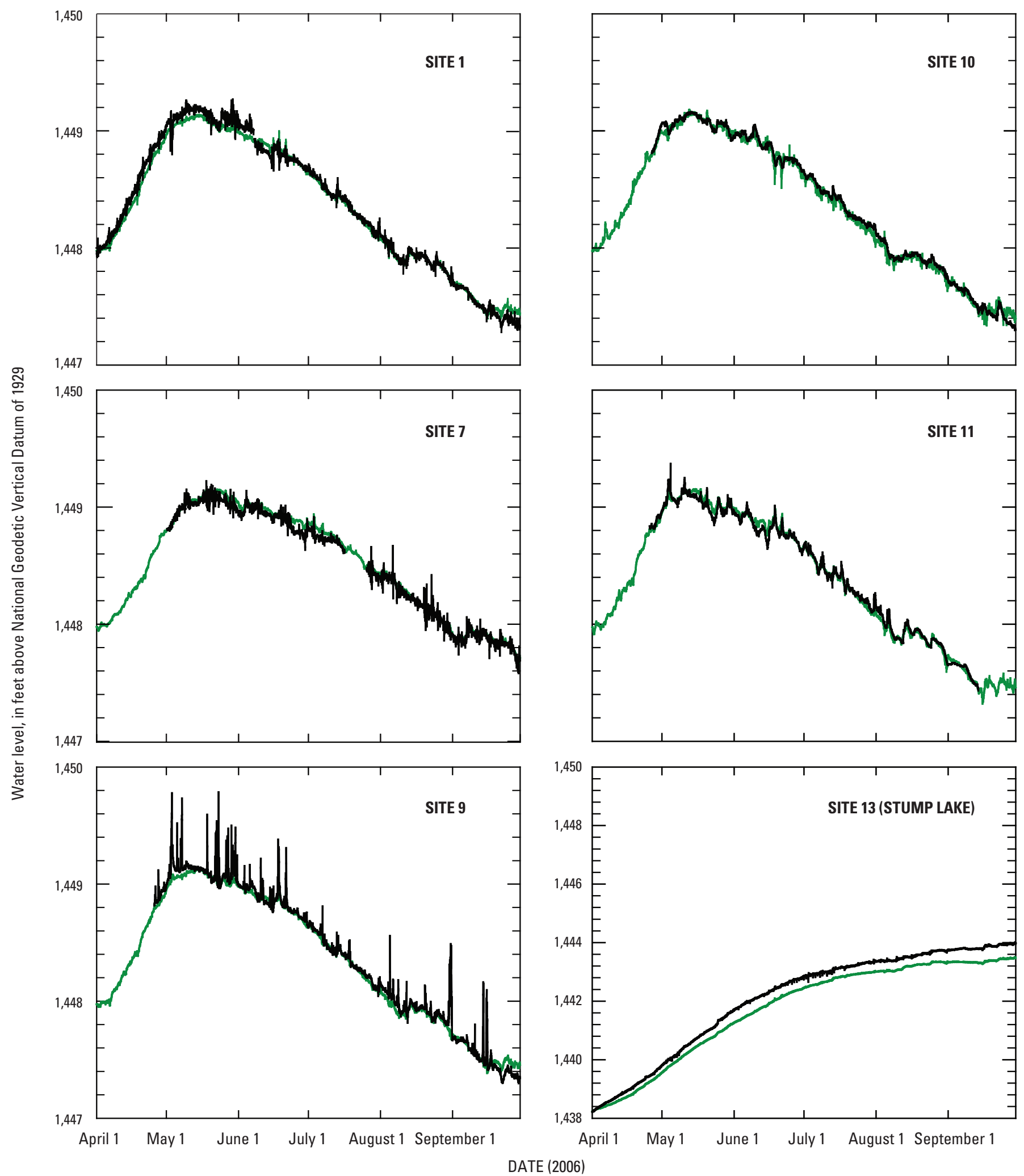

EXPLANATION

- Simulated

Measured

Figure 13. Simulated and measured water levels for selected sites on Devils Lake and Stump Lake, North Dakota, April 1 through September 30, 2006. 
Table 4. Goodness-of-fit water-level statistics for the calibration of the Devils Lake model, North Dakota, April 1 through September 30, 2006.

[NGVD 29: National Geodetic Vertical Datum of 1929. The mean measured water level was computed from all available hourly values from April 1 through September 30, 2006. Some measured hourly values were missing at all sites, with some sites missing more values than others. The mean simulated water level was computed from hourly values from April 1 through September 30, 2006. As a result, the difference between the mean measured water level and the mean simulated water level may be slightly different than the mean error.]

\begin{tabular}{ccccccc}
\hline Site & $\begin{array}{c}\text { Mean measured } \\
\text { water level, } \\
\text { in feet above } \\
\text { NGVD 29 }\end{array}$ & $\begin{array}{c}\text { Mean simulated } \\
\text { water level, } \\
\text { in feet above } \\
\text { NGVD 29 }\end{array}$ & $\begin{array}{c}\text { Maximum measured } \\
\text { water level, } \\
\text { in feet above } \\
\text { NGVD 29 }\end{array}$ & $\begin{array}{c}\text { Maximum simulated } \\
\text { water level, } \\
\text { in feet above } \\
\text { NGVD 29 }\end{array}$ & $\begin{array}{c}\text { Mean error, } \\
\text { in feet }\end{array}$ & $\begin{array}{c}\text { Root mean } \\
\text { square error, } \\
\text { in feet }\end{array}$ \\
\hline 1 & $1,448.37$ & $1,448.35$ & $1,449.27$ & $1,449.14$ & 0.02 & 0.06 \\
7 & $1,448.32$ & $1,448.35$ & $1,449.22$ & $1,449.15$ & -.03 & .06 \\
9 & $1,448.39$ & $1,448.35$ & $1,449.79$ & $1,449.13$ & .03 & .10 \\
10 & $1,448.36$ & $1,448.35$ & $1,449.16$ & $1,449.18$ & .01 & .04 \\
11 & $1,448.46$ & $1,448.35$ & $1,449.37$ & $1,449.18$ & .00 & .04 \\
13 & $1,442.10$ & $1,441.75$ & $1,444.01$ & $1,443.50$ & .34 & .36 \\
\hline
\end{tabular}

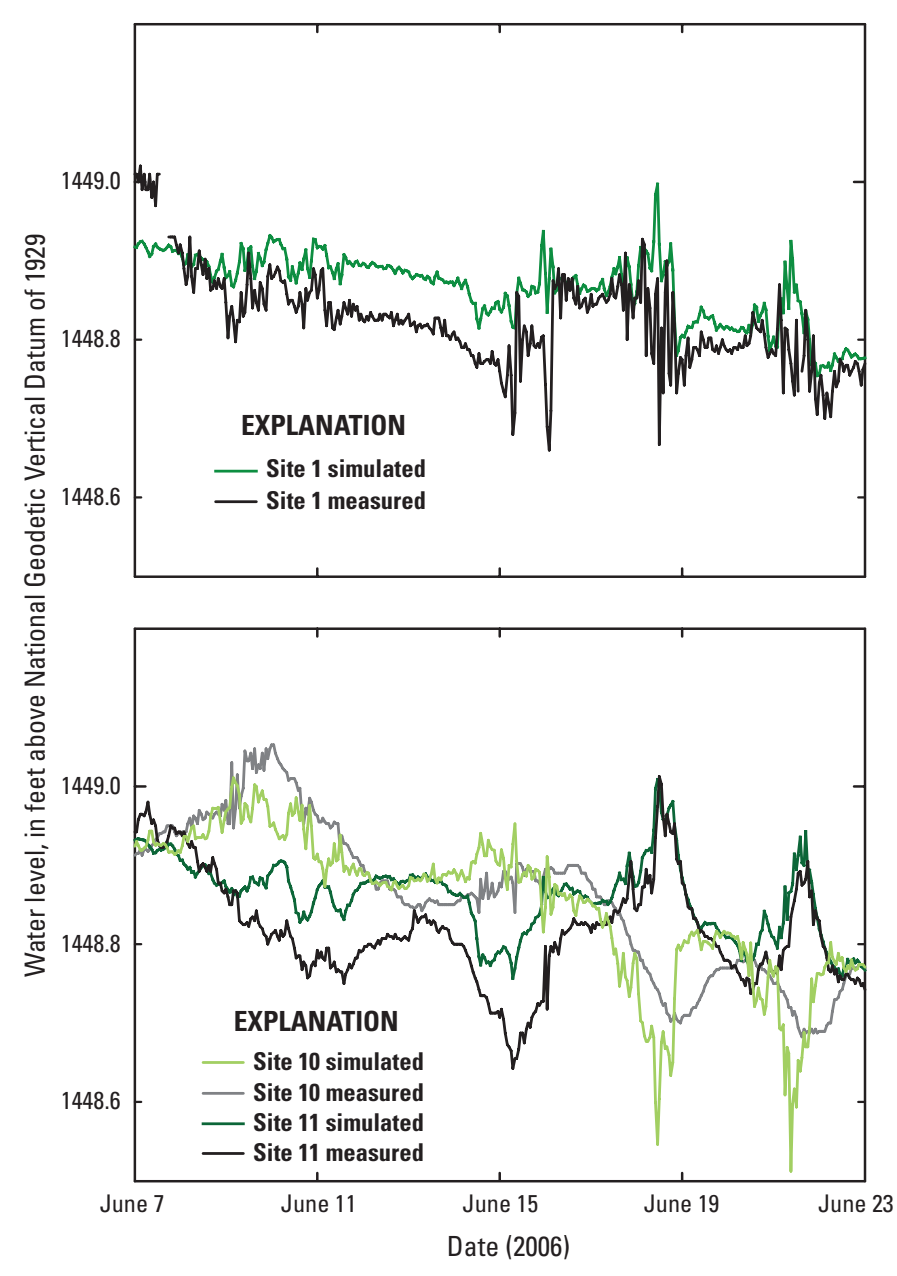

Figure 14. Simulated and measured water levels for selected sites on Devils Lake and Stump Lake, North Dakota, June 7 through 23, 2006. the physical orientation of the bridge opening at site 12 is nearly due east-west, but within the model grid the bridge opening is slightly rotated to the east so the direction of flow is along a line between 280 to 100 degrees from north. In addition, the area of the bridge openings depicted in the model grid may be slightly larger than the actual area, which may be causing the simulated current speeds to be less than measured current speeds. For this application, simulated water levels for the extreme flooding scenario (discussed in the Model Application section) were insensitive to the current configuration of the bridge openings in the model grid, but in further applications, the fit between simulated and measured current speeds may be improved by more accurately defining the physical configuration of the bridge openings in the model grid.

It should also be noted that measured current speeds likely have some error in them as well. Although AVM technology generally is reliable and accurate for measuring water-current profiles, there are some inherent limitations and assumptions associated with AVM measurements. The AVM determines velocity from a Doppler (frequency) shift in the acoustic beams from backscattered signals, which means that it actually is measuring the motion of the particles in the water, not the actual water motion, which may be different. Also, three-dimensional velocity components collected from an AVM are collected from a minimum of three beams, and it is assumed that the flow measured in each beam is the same (homogeneous). Therefore, velocities measured in flow conditions with high and rapid spatial variations are less certain (Mueller and Wagner, 2009). As illustrated previously (fig. 9), the flow within the bridge openings at sites 8 and 12 changes rapidly, which likely contributes to error in the measured current speeds.

Overall, simulated water levels in Devils Lake compared well with measured water levels. The maximum simulated water level at site 1 was within $0.13 \mathrm{ft}$ of the maximum 
Table 5. Goodness-of-fit current speed statistics for the calibration of the Devils Lake model, North Dakota, April 1 through September 30, 2006.

[The mean measured current speed was computed from all available daily values from April 1 through September 30, 2006. Some measured daily values were missing. The mean simulated current speed was computed from daily values from April 1 through September 30, 2006. As a result, the difference between the mean measured current speed and the mean simulated current speed is slightly different than the mean error.]

\begin{tabular}{rrrrr}
\hline Site & $\begin{array}{c}\text { Mean } \\
\text { measured } \\
\text { current } \\
\text { speed, } \\
\text { in feet per } \\
\text { second }\end{array}$ & $\begin{array}{c}\text { Mean } \\
\text { simulated } \\
\text { current } \\
\text { speed, } \\
\text { in feet per } \\
\text { second }\end{array}$ & $\begin{array}{c}\text { Mean error, } \\
\text { in feet per } \\
\text { second }\end{array}$ & $\begin{array}{c}\text { Root mean } \\
\text { square } \\
\text { error, } \\
\text { in feet per } \\
\text { second }\end{array}$ \\
\hline 8 & 0.58 & 0.40 & 0.20 & 0.26 \\
12 & .69 & .36 & .32 & .41 \\
\hline
\end{tabular}

measured water level in the calibration, which gives reasonable confidence that the Devils Lake model is able to accurately simulate the maximum water level at site 1 for the extreme flooding scenario. The timing and direction of winddriven fluctuations in water levels on a short time scale (a few hours to a day) were reproduced well by the Devils Lake model. For this application, the Devils Lake model was not optimized for simulation of the current speed through bridge openings. In future applications, simulation of current speed through bridge openings could be improved by more accurate definition of the bathymetry and geometry of select areas in the model grid.

\section{Model Performance Testing}

As a test of the performance of the Devils Lake model, a simulation of 2009 conditions from April 1 through September 30, 2009 was performed. Of particular interest in the 2009 conditions, Devils Lake and Stump Lake started out at the same water level in April, but during spring runoff, the water level in Devils Lake rose more quickly than Stump Lake, resulting in a period of time in which Devils Lake was higher than Stump Lake. A simulation of the 2009 conditions was performed to determine how well the Devils Lake model reproduced this condition. For 2009, measured inflows for Big Coulee and Channel A were not available, so daily inflows for the tributaries of Big Coulee and Channel A were estimated from a model of the chain of lakes from the National Weather Service (NWS) (Brian Connelly, National Weather Service, written commun., 2010). Inflows for Big Coulee were estimated as the outflow from Lake Irvine and inflows for Channel A were estimated as the outflow from Dry Lake, which is upstream from the locations (sites 2 and 3 ) used in the 2006 calibration (fig. 1). Daily inflows for Little Coulee were available from the same site (site 4) as that used in the 2006 calibration (U.S. Geological Survey, 2009). Because the estimates for Big Coulee and Channel A were upstream from sites 2 and 3, ungaged inflow was assumed to be accounted for in the inflow estimates. Other than ungaged inflows to Devils Lake (ungaged inflows to Stump Lake were included), other inputs for the 2009 simulation were the same as those used in the 2006 calibration. Wind speed and direction were compiled from the Crary $1 \mathrm{E}$ weather station. Precipitation and evapotranspiration, as an average of the Crary 1E and Baker 1N weather stations, were compiled and outflows from the Devils Lake State Outlet were available from the NDSWC ( $h t t p: / /$ ndawn.ndsu.nodak.edu/hourly-table-form.html, accessed August 27, 2010; http://www.swc.state.nd.us/4dlink9/4dcgi/ GetSubCategoryRecord/Devils\%20Lake\%20Flooding/Outlet, accessed August 27, 2010). The same multipliers (table 3) determined during the 2006 calibration were used in calculating $N E(t)$. Initial water levels for Devils Lake and Stump Lake were set to the April 1 measured elevation of 1,447.5 feet for sites 1 and 13 .

Because the 2009 inflows were not as accurate as the measured inflows used in model calibration, goodness-of-fit statistics were not computed. Rather general comparisons were made between simulated and measured water levels for Devils Lake (site 1) and Stump Lake (site 13) (fig. 17). Several patterns emerge in the simulated water levels for 2009 that can be related to patterns in the estimated inflows (fig. 18). The nearly unchanging water levels at the beginning of the 2009 simulation are directly related to the minimal inflows estimated for 2009 (figs. 17 and 18). About April 15, simulated water levels start increasing rapidly (fig. 17), which corresponds directly to the rapid increase in estimated inflows (fig. 18). Based on the appearance of measured 2009 water levels, it seems likely that the inflows did start increasing earlier in April than what was estimated. During the rising phase from April to June, similar to the measured water levels, the simulated water level on Devils Lake rose faster than Stump Lake resulting in a period of time in which Devils Lake was higher than Stump Lake (fig.17). The magnitude of the difference in simulated water levels between Devils Lake and Stump Lake during the rising phase is similar to the difference observed in the measured water levels. The rate of rise for simulated water levels for both sites is greater than the rate of rise for the measured water levels, which most likely is related to uncertainty in the inflow estimates. After the maximum water level is reached around June 28, simulated water levels are consistently higher than the measured water levels. This may be related to total inflows for Big Coulee and Channel A being slightly overestimated (Brian Connelly, National Weather Service, written commun., 2010), and possibly some error in net evaporation. Similar to the 2006 calibration, the timing and direction of wind-driven fluctuations in water levels on a short time scale are reproduced well by the Devils Lake model, although, the magnitude of fluctuations are reduced compared to measured water levels (fig. 17). This likely is related to two factors: daily values were used for the 2009 inflows and flow reversals in Big Coulee, and Channel A could not be estimated for the 2009 inflows. Also subsequent to about June 28, the difference between simulated water levels for Devils Lake and Stump Lake was 

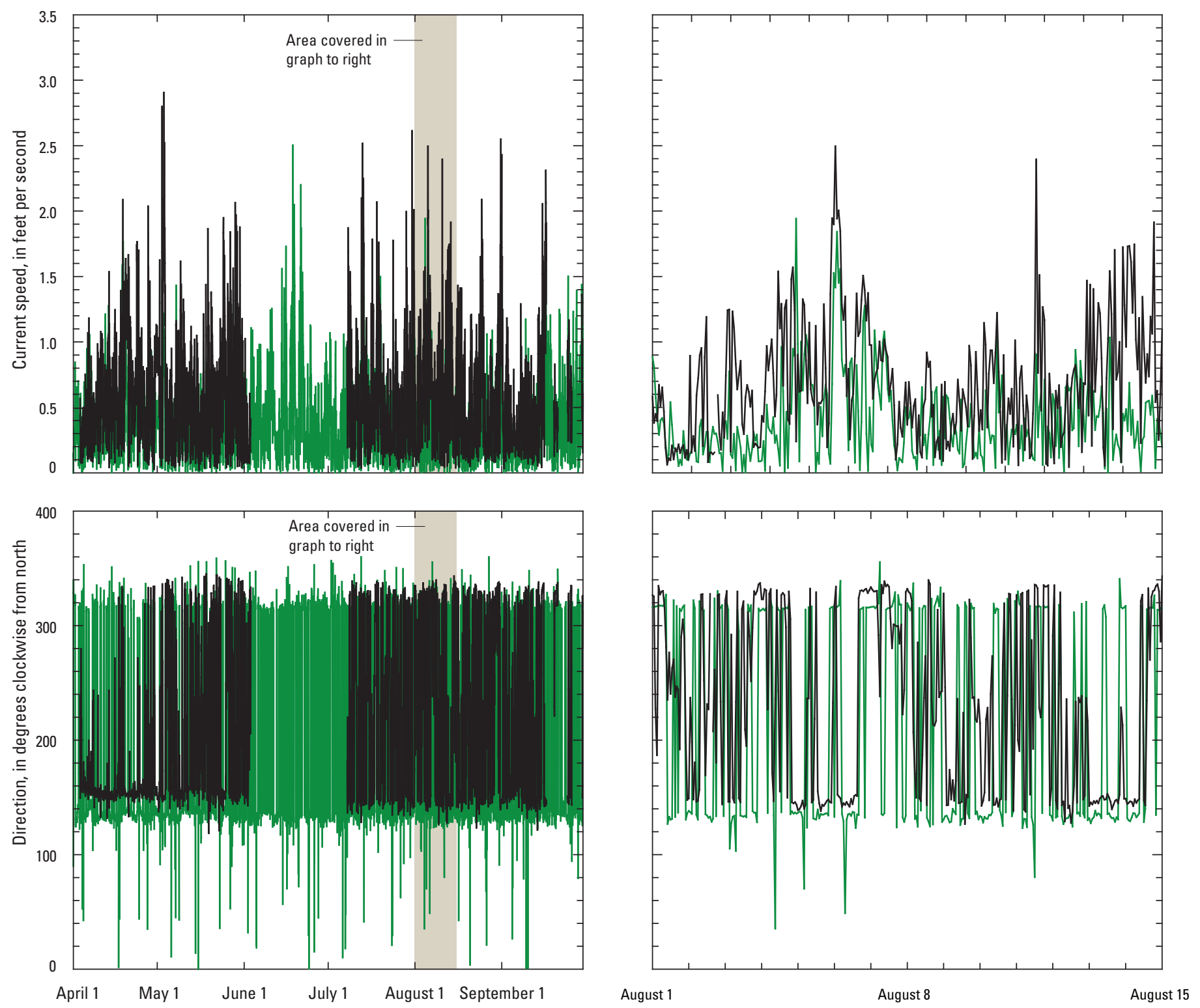

Date (2006)

EXPLANATION

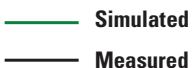

Figure 15. Simulated and measured current speed and direction for Devils Lake, North Dakota at site 8, April 1 through September 30, 2006. 

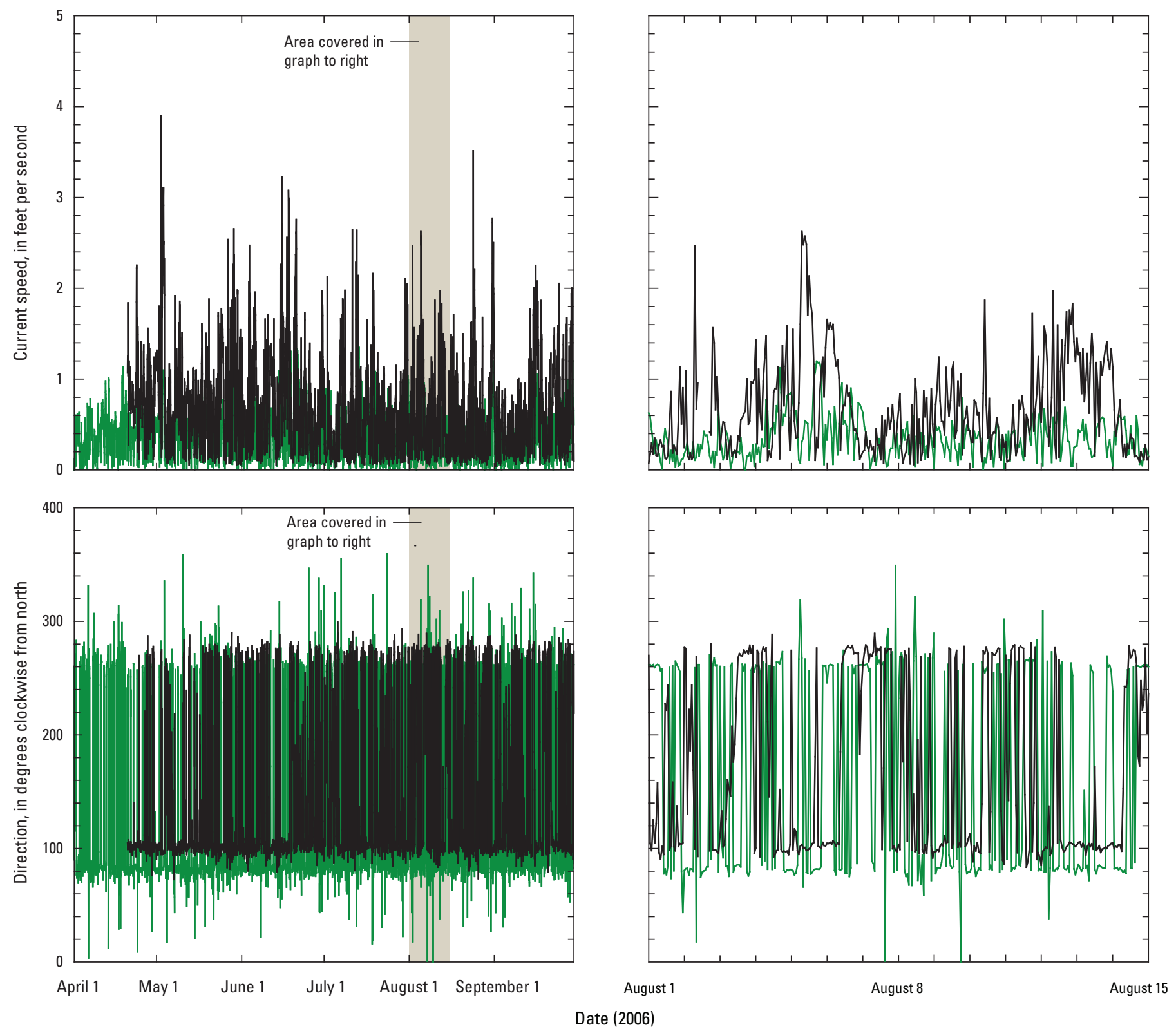

Date (2006)

EXPLANATION

Figure 16. Simulated and measured current speed and direction for Devils Lake, North Dakota at site 12, April 1 through September 30, 2006. 


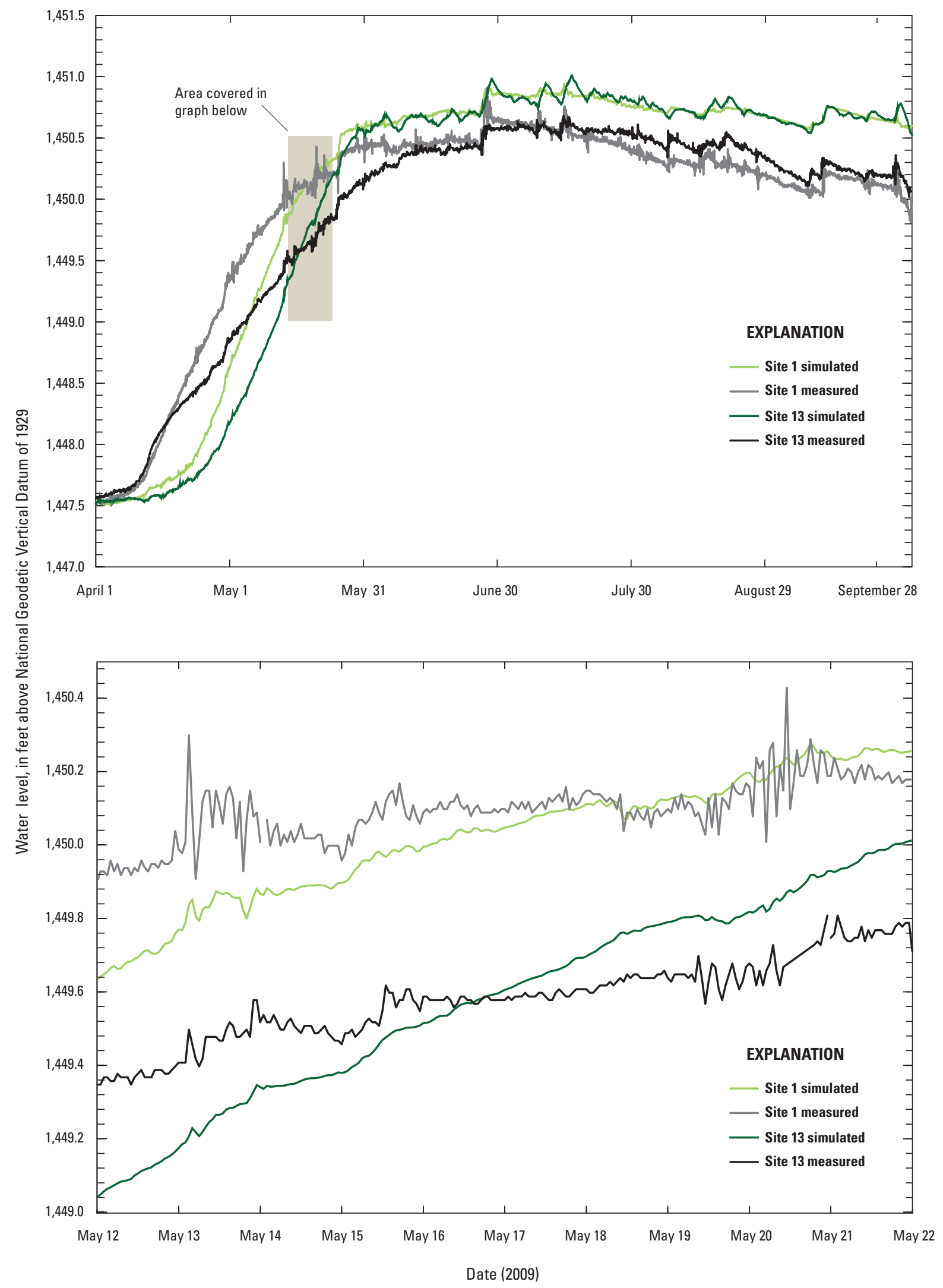

Figure 17. Simulated and measured water levels for Devils Lake (site 1) and Stump Lake (site 13), North Dakota, April 1 through September 30, 2009. 
Figure 18. Estimated daily inflows to Devils Lake, North Dakota and precipitation measured at the Crary $1 \mathrm{E}$ North Dakota Agricultural Weather Network station, located near Crary, North Dakota, 2009.

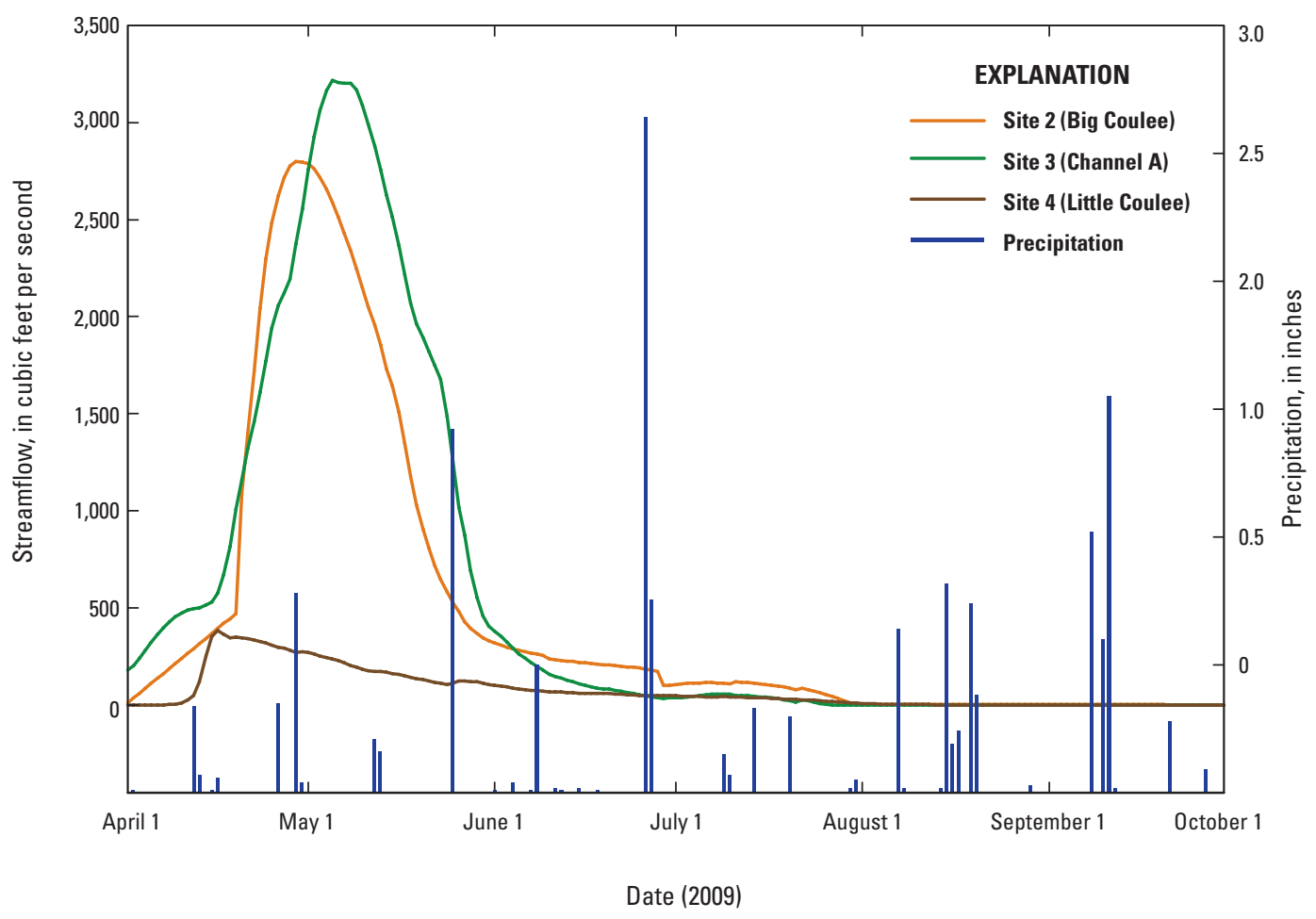

$0.10 \mathrm{ft}$ or less, compared to $0.25 \mathrm{ft}$ for the measured water levels. The smaller difference between simulated water levels may be related to the absence of elevation errors in the Devils Lake model and uniform evaporation being applied to both lakes. Overall, errors in inflow estimates affected the results for the 2009 simulation; however, for the rising phase of the lakes, the Devils Lake model accurately simulated the faster rate of rise in Devils Lake than in Stump Lake, and timing and direction of wind-driven fluctuations in water levels on a short time scale were reproduced well.

\section{Model Application}

As water levels continue to rise in Devils Lake, watermanagement issues also arise. To aid in addressing a couple of those water-management issues, the calibrated Devils Lake model was used to simulate the effects of an extreme flooding event on water levels and the effects of hydrological modifications within the lake on the transport of dissolved solids through Devils Lake and Stump Lake.

\section{Extreme Flooding Scenario}

In 2009, in response to forecasted water levels, the USACE began working on another raise and extension of the protective embankment around the city of Devils Lake (North Dakota State Water Commission, 2010). To help the USACE determine the elevation to which the protective embankment for the city of Devils Lake should be raised, an extreme flooding scenario based on an inflow of one-half the probable maximum flood (PMF) was simulated using the Devils Lake model. Based on comparison with similar basins, the PMF for the Devils Lake Basin was estimated to be 2.88 million acre feet (MAF) by the USACE (Jonathan Petersen, U.S. Army Corps of Engineers, written commun., 2009). For design purposes, the USACE chose to assume an inflow equivalent to one-half the PMF, or 1.44 MAF to the Devils Lake Basin (Jonathan Petersen, U.S. Army Corps of Engineers, written commun., 2009). (To put the one-half PMF inflow into perspective, of the inflows to the Devils Lake Basin measured in the past 60 years, the largest annual inflow to the Devils Lake Basin occurred in 2009 with an estimated volume of 590,000 acre-ft (fig. 5), which means that the 1.44 MAF (one-half PMF) inflow, is more than double the 2009 inflows.) In addition to the assumption of 1.44 MAF of inflow for the extreme flooding scenario, the USACE chose to assume an initial water level of 1,458.0 ft, the water level at which Stump Lake overflows into the Tolna Coulee. Although the initial water level of $1,458.0$ feet is $10 \mathrm{ft}$ higher than the 2006 calibration, the maximum water level at site 1 for the calibration was accurately simulated giving confidence in the simulated maximum water level for the extreme flooding scenario.

At a water level of 1,458.0 ft, 29.8 percent of the total area of the Devils Lake Basin is contained in the upstream chain of lakes and is outside of the model grid. Therefore, 29.8 percent of the total 1.44 MAF (0.43 MAF) was assumed to go toward increased storage upstream from the model grid. 
The remaining 1.01 MAF was apportioned to all six inflow locations (fig. 12) based on drainage area (table 6). Inflow was assumed to happen as a triangular hydrograph through a 120day period, with the peak inflow occurring 60 days after the beginning of the flood (Jonathan Petersen, U.S. Army Corps of Engineers, written commun., 2009).

Wind conditions and $N E(t)$ from 2006 were used and applied uniformly over the lake. To accommodate overflow from Stump Lake, an outlet to Tolna Coulee was defined in the model grid (fig. 12). Overflow from Stump Lake was estimated based on a rating curve supplied by the USACE, which assumes no erosion of the outlet (Jonathan Petersen, U.S. Army Corps of Engineers, written commun., 2009).

Because it was assumed that Graham's Island Road would not be maintained when water levels reached $1,458.0 \mathrm{ft}$, it was not included in the model grid.

Simulated results were reported for sites 1, 13, and one additional site on the protective embankment surrounding the city of Devils Lake (referred to as the embankment site). Results for the additional site were included to determine if maximum water levels were different along the protective embankment. Similar to the 2009 simulation, both lakes started at the same water level, but, unlike 2009, both lakes basically rose together at the same rate. Although Stump Lake reached a maximum water level of $1,462.1 \mathrm{ft}$, it was windrelated, and generally, under the conditions and assumptions of the extreme flooding scenario, the water level for all sites reached a maximum water level around $1,461.9 \mathrm{ft}$ (table 7 and fig.19). For both lakes, water levels remained above $1,461.5 \mathrm{ft}$ for approximately 33 consecutive days.

To test the sensitivity of water-level results to the assumed conditions for the extreme flooding scenario, four

Table 6. Inflow volumes and locations used for an extreme flooding scenario in the Devils Lake model.

\begin{tabular}{lcc}
\hline \multicolumn{1}{c}{$\begin{array}{c}\text { Inflow location } \\
\text { (fig. 12) }\end{array}$} & $\begin{array}{c}\text { Distribution of } \\
\text { one-half probable } \\
\text { maximum flood } \\
\text { inflow, } \\
\text { in percent }\end{array}$ & $\begin{array}{c}\text { Flow, } \\
\text { in million-acre } \\
\text { feet }\end{array}$ \\
\hline Stump Lake & 12.5 & 0.18 \\
Devils Lake (West Bay) & 6.5 & .094 \\
Devils Lake (East Bay) & 13.1 & .189 \\
Little Coulee & 6.3 & .091 \\
Big Coulee & 18.4 & .265 \\
Channel A & 13.4 & .193 \\
Total inflow to model grid & 70.2 & 1.01 \\
Remaining volume in stor- & 29.8 & .43 \\
age in the upstream chain \\
of lakes (Sweetwater
\end{tabular}

Table 7. Maximum and mean simulated water levels for an extreme flooding scenario using the Devils Lake model for sites on Devils Lake (site 1 and embankment) and Stump Lake (site 13).

[NGVD 29, National Geodetic Vertical Datum of 1929]

\begin{tabular}{lccc}
\hline $\begin{array}{c}\text { Site } \\
\text { (fig. 1) }\end{array}$ & $\begin{array}{c}\text { Maximum } \\
\text { water level, } \\
\text { in feet above } \\
\text { NGVD 1929 }\end{array}$ & $\begin{array}{c}\text { Number } \\
\text { of days to } \\
\text { maximum } \\
\text { water level }\end{array}$ & $\begin{array}{c}\text { Mean water level, } \\
\text { in feet above } \\
\text { NGVD 1929 }\end{array}$ \\
\hline 1 & $1,461.9$ & 91 & $1,460.3$ \\
Embankment & $1,461.9$ & 91 & $1,460.3$ \\
13 & $1,462.1$ & 79 & $1,460.2$ \\
\hline
\end{tabular}

simulations were performed in which certain conditions were changed. Simulations were made in which (1) Manning's $n$ was increased to 0.06 , (2) Manning's $n$ was reduced to 0.02 , (3) the bridge width at site 8 was narrowed by about 30 percent, and (4) Graham's Island Road was defined in the model grid. Water-level results were most sensitive to an increase in the Manning's $n$ (table 8). The maximum water level in Devils Lake was increased by $0.2 \mathrm{ft}$ when the Manning's $n$ was increased to 0.06 . Water-level results were insensitive to bridge and road modifications as indicated by the small change in water levels (table 8).

\section{Transport of Dissolved Solids}

As Devils Lake continues to rise, the NDSWC has been investigating possibilities on how to increase pumping from the Devils Lake State Outlet. One factor limiting the extent of pumping is sulfate concentrations in West Bay. If sulfate concentrations can be reduced in West Bay, pumping from the Devils Lake State Outlet potentially can increase. A few hydrological modifications to the Devils Lake system which potentially could reduce sulfate concentrations in West Bay would be: (1) divert inflows from Channel A into Big Coulee, (2) reduce water exchange between Main Bay (lower sulfate concentration) and East Bay (higher sulfate concentration), or (3) divert Channel A and reduce the area of water exchange between Main Bay and East Bay.

Using the Devils Lake model, the transport of dissolved solids was simulated using SC data as a surrogate for sulfate. $\mathrm{SC}$ was used because more data were available compared to sulfate data; however, there were still insufficient data available for calibration of dissolved solids transport. Because the transport of dissolved solids was not calibrated, results from the simulations were not actual expected concentrations. However, the effects of hydrological modifications on dissolved solids concentrations could be evaluated by comparing the effects of hydrological modifications relative to a baseline condition in which no hydrological modifications were made.

Four scenarios were simulated: (1) baseline condition (no hydrological modification), (2) diversion of Channel A (inflows from Channel A were added to Big Coulee), (3) 
Figure 19. Simulated water levels using the Devils Lake model for sites on Devils Lake (site 1 and embankment) and Stump Lake (site 13), North Dakota for an extreme flooding scenario.

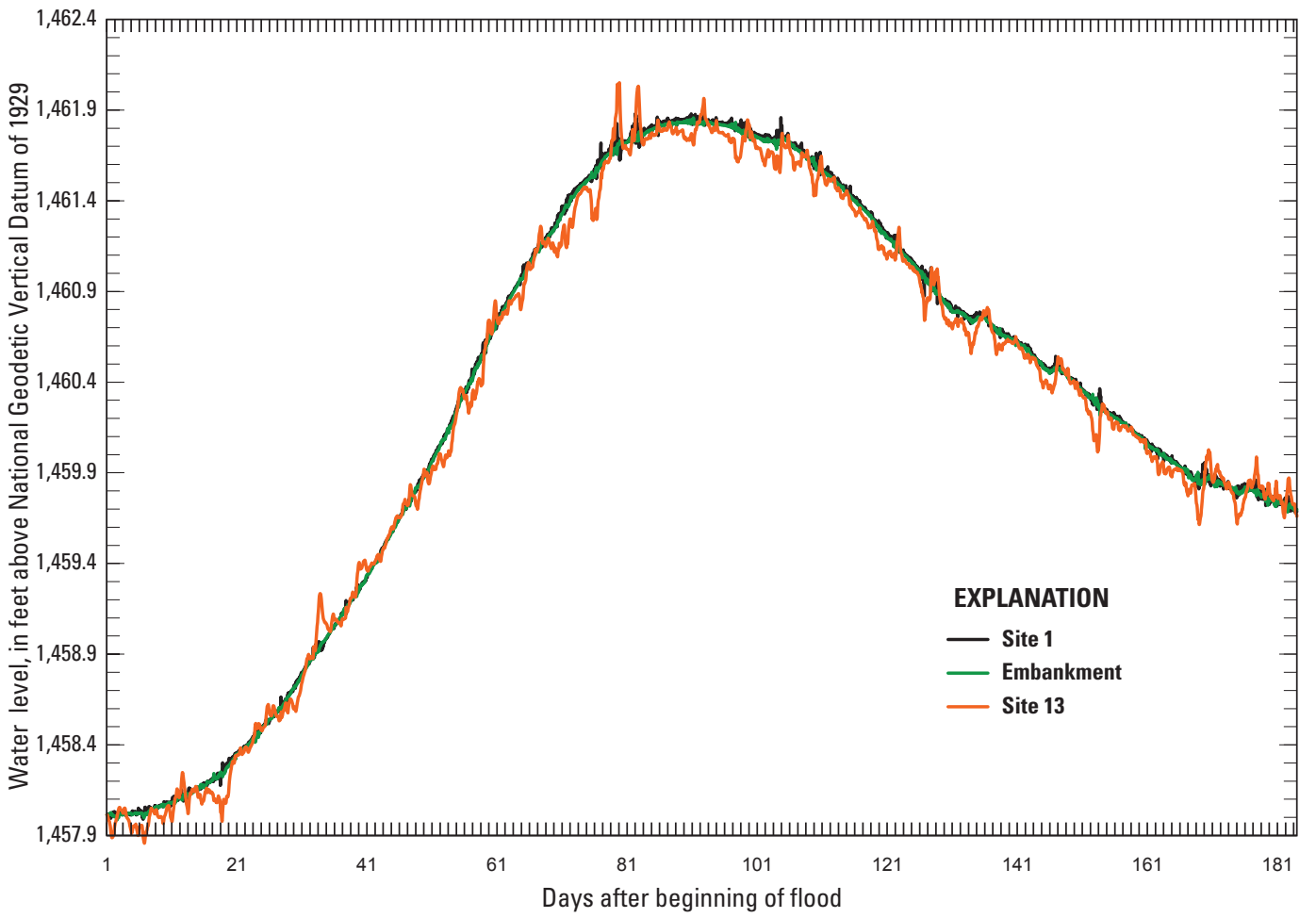

reduction of the area of water exchange between Main Bay and East Bay (in the model grid, the bottom elevation in the bridge opening at site 8 was raised to 1,446.0 ft), and (4) a combination of scenarios 2 and 3 . Each scenario was simulated over 4 consecutive years to try to determine longer term effects of the hydrologic modifications. A pattern of 1 year of large inflow followed by 2 years of no inflow and finally, 1 more year of large inflow was simulated. Because ice cover was not simulated with the Devils Lake model, a simulation year was the 6-month period from April 1 through September 30 . For this preliminary work, SC was treated as a conservative tracer, which means that the concentration effects of evaporation were not included (although the dilution effects of precipitation were included). In future studies, the concentration effects of evaporation can be added and would likely improve the accuracy of the model. The concentration effects were expected to be small, although not negligible. For example, based on conditions from the 2009 simulation, about 21 in. of water evaporated between April and September, and the average depth of the model grid was 20 feet. The average measured SC in 2009 for all the bays was about $3,100 \mu \mathrm{S} \mathrm{cm}^{-1}$. Given an SC value of $3,100 \mu \mathrm{S} \mathrm{cm}^{-1}$ and redistributing 21 in. of evaporated water over a 20 -ft column of water, the SC concentration of the water column would increase by about 210 $\mu \mathrm{S} \mathrm{cm} \mathrm{cm}^{-1}$ or 6.8 percent.

Because the effects of the hydrological modification were going to be assessed on a relative basis, and a complete set of boundary conditions was not available from a single year, a combination of data from 2006 and 2009 were used for boundary conditions (table 9).

Inflows from 2009 were used for year 1 and 4, and zero inflow was used for years 2 and 3. For scenarios 2 and 4, Channel A inflows were added to Big Coulee inflows. For all simulation years, the $N E(t)$ and wind speed and direction from

Table 8. Comparison of simulated water-level results for Devils Lake (site 1) and Stump Lake, North Dakota (site 13) for four changes in conditions in the Devils Lake model for an extreme flooding scenario.

[Condition 1, Manning's $n$ increased to 0.06 ; Condition 2, Manning's $n$ reduced to 0.02 ; Condition 3, bridge width at site 8 narrowed by about 30 percent; Condition 4, Graham's Island Road defined in the model grid]

\begin{tabular}{|c|c|c|c|c|c|c|c|c|}
\hline $\begin{array}{c}\text { Site } \\
\text { (fig.1) }\end{array}$ & $\begin{array}{c}\text { Change in } \\
\text { mean } \\
\text { lake level, } \\
\text { in feet }\end{array}$ & $\begin{array}{c}\text { Change in } \\
\text { maximum } \\
\text { lake level, } \\
\text { in feet }\end{array}$ & $\begin{array}{l}\text { Change in } \\
\text { mean } \\
\text { lake level, } \\
\text { in feet }\end{array}$ & $\begin{array}{c}\text { Change in } \\
\text { maximum } \\
\text { lake level, } \\
\text { in feet }\end{array}$ & $\begin{array}{l}\text { Change in } \\
\text { mean } \\
\text { lake level, } \\
\text { in feet }\end{array}$ & $\begin{array}{c}\text { Change in } \\
\text { maximum } \\
\text { lake level, } \\
\text { in feet }\end{array}$ & $\begin{array}{l}\text { Change in } \\
\text { mean } \\
\text { lake level, } \\
\text { in feet }\end{array}$ & $\begin{array}{c}\text { Change in } \\
\text { maximum } \\
\text { lake level, } \\
\text { in feet }\end{array}$ \\
\hline 1 & $0.17^{\mathrm{a}}$ & 0.22 & $-0.03^{b}$ & -0.03 & 0 & 0 & 0 & -0.01 \\
\hline 13 & .16 & .08 & -.02 & .09 & 0 & 0 & 0 & 0 \\
\hline
\end{tabular}

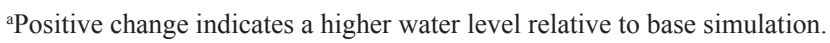

${ }^{b}$ Negative change indicates a lower water level relative to base simulation. 
Table 9. Boundary conditions used for simulation of specific conductance for different scenarios in Devils Lake, North Dakota.

$\left[\mathrm{ft}^{3} / \mathrm{s}\right.$, cubic feet per second; $\mu \mathrm{S} \mathrm{cm}-1$, microsiemens per centimeter; ${ }^{\circ} \mathrm{C}$, degrees Celsius; --, not applicable; $\mathrm{Q}$, streamflow]

\begin{tabular}{|c|c|c|c|c|c|}
\hline Boundary Condition & Location & Scenario 1 & Scenario 2 & Scenario 3 & Scenario 4 \\
\hline \multicolumn{6}{|c|}{ Year 1} \\
\hline \multirow[t]{3}{*}{ Total inflow, in acre-feet } & Big Coulee (site 2) & 169,000 & 371,000 & 169,000 & 371,000 \\
\hline & Channel A (site 3) & 202,000 & 0 & 202,000 & 0 \\
\hline & Little Coulee (site 4) & 27,500 & 27,500 & 27,500 & 27,500 \\
\hline Daily outflow volume, in $\mathrm{ft}^{3} / \mathrm{s}$ & & 250 & 250 & 250 & 250 \\
\hline \multirow[t]{3}{*}{ Constant specific conductance, in $\mu \mathrm{S} \mathrm{cm}^{-1}$} & Big Coulee (site 2) & 767 & 634 & 767 & 634 \\
\hline & Channel A (site 3) & 524 & -- & 524 & -- \\
\hline & Little Coulee (site 4) & 2,000 & 2,000 & 2,000 & 2,000 \\
\hline \multirow[t]{3}{*}{ Water temperature, in ${ }^{\circ} \mathrm{C}$} & Big Coulee (site 2) & \multicolumn{4}{|c|}{ daily water temperature measured in 2006} \\
\hline & Channel A (site 3) & \multicolumn{4}{|c|}{ daily water temperature measured in 2006} \\
\hline & Little Coulee (site 4) & \multicolumn{4}{|c|}{ daily water temperature measured in 2006 from site 2} \\
\hline \multirow[t]{7}{*}{ Initial specific conductance, in $\mu \mathrm{S} \mathrm{cm}^{-1}$} & Pelican Lake & 1,920 & 1,920 & 1,920 & 1,920 \\
\hline & Sixmile bay & 2,090 & 2,090 & 2,090 & 2,090 \\
\hline & West Bay & 2,270 & 2,270 & 2,270 & 2,270 \\
\hline & Main Bay & 2,310 & 2,310 & 2,310 & 2,310 \\
\hline & East Bay & 2,890 & 2,890 & 2,890 & 2,890 \\
\hline & East Devils Lake & 3,400 & 3,400 & 3,400 & 3,400 \\
\hline & Stump Lake & 6,630 & 6,630 & 6,630 & 6,630 \\
\hline \multicolumn{6}{|c|}{ Year 2} \\
\hline \multirow[t]{3}{*}{ Total inflow, in acre-feet } & Big Coulee (site 2) & 0 & 0 & 0 & 0 \\
\hline & Channel A (site 3) & 0 & 0 & 0 & 0 \\
\hline & Little Coulee (site 4) & 0 & 0 & 0 & 0 \\
\hline Daily outflow volume, in $\mathrm{ft}^{3} / \mathrm{s}$ & & 250 & 250 & 250 & 250 \\
\hline \multirow[t]{3}{*}{ Constant specific conductance, in $\mu \mathrm{S} \mathrm{cm}^{-1}$} & Big Coulee (site 2) & -- & -- & -- & -- \\
\hline & Channel A (site 3) & -- & -- & -- & -- \\
\hline & Little Coulee (site 4) & -- & -- & -- & -- \\
\hline \multirow[t]{3}{*}{ Water temperature, in ${ }^{\circ} \mathrm{C}$} & Big Coulee (site 2) & -- & -- & -- & -- \\
\hline & Channel A (site 3) & -- & -- & -- & -- \\
\hline & Little Coulee (site 4) & -- & -- & -- & -- \\
\hline \multirow[t]{7}{*}{ Initial specific conductance, in $\mu \mathrm{S} \mathrm{cm}^{-1}$} & Pelican Lake & 1,450 & 1,050 & 1,460 & 1,050 \\
\hline & Sixmile bay & 1,990 & 2,270 & 1,970 & 2,250 \\
\hline & West Bay & 2,060 & 1,810 & 2,070 & 1,800 \\
\hline & Main Bay & 2,060 & 2,290 & 2,030 & 2,270 \\
\hline & East Bay & 2,760 & 2,780 & 2,780 & 2,800 \\
\hline & East Devils Lake & 3,290 & 3,290 & 3,300 & 3,300 \\
\hline & Stump Lake & 6,310 & 6,310 & 6,310 & 6,310 \\
\hline \multicolumn{6}{|c|}{ Year $3^{\mathrm{a}}$} \\
\hline \multirow[t]{5}{*}{ Initial specific conductance, in $\mu \mathrm{S} \mathrm{cm}^{-1}$} & Pelican Lake & 1,690 & 1,360 & 1,700 & 1,350 \\
\hline & Sixmile bay & 2,110 & 2,300 & 2,070 & 2,270 \\
\hline & West Bay & 2,030 & 1,860 & 2,030 & 1,850 \\
\hline & Main Bay & 2,130 & 2,310 & 2,080 & 2,280 \\
\hline & East Bay & 2,740 & 2,780 & 2,780 & 2,810 \\
\hline
\end{tabular}


Table 9. Boundary conditions used for simulation of specific conductance for different scenarios in Devils Lake, North Dakota.Continued

$\left[\mathrm{ft}^{3} / \mathrm{s}\right.$, cubic feet per second; $\mu \mathrm{S} \mathrm{cm}-1$, microsiemens per centimeter; ${ }^{\circ} \mathrm{C}$, degrees Celsius; --, not applicable; $\mathrm{Q}$, streamflow $]$

\begin{tabular}{|c|c|c|c|c|c|}
\hline Boundary Condition & Location & Scenario 1 & Scenario 2 & Scenario 3 & Scenario 4 \\
\hline \multicolumn{6}{|c|}{ Year $3^{\mathrm{a}}$-Continued } \\
\hline & East Devils Lake & 3,320 & 3,410 & 3,340 & 3,340 \\
\hline \multicolumn{6}{|c|}{ Year $4^{b}$} \\
\hline \multirow[t]{6}{*}{ Initial specific conductance, in $\mu \mathrm{S} \mathrm{cm}^{-1}$} & Pelican Lake & 1,830 & 1,570 & 1,830 & 1,560 \\
\hline & West Bay & 2,030 & 1,920 & 2,020 & 1,900 \\
\hline & Main Bay & 2,180 & 2,330 & 2,120 & 2,290 \\
\hline & East Bay & 2,730 & 2,780 & 2,790 & 2,830 \\
\hline & East Devils Lake & 3,350 & 3,430 & 3,390 & 3,390 \\
\hline & Stump Lake & 6,290 & 6,290 & 6,290 & 6,290 \\
\hline
\end{tabular}

${ }^{\mathrm{a}}$ Other than initial specific conductance conditions, all boundary conditions the same as year 2 .

${ }^{\mathrm{b}}$ Other than initial specific conductance conditions, all boundary conditions the same as year 1.

the 2009 simulation was used. For all simulation years, 2009 meteorological data including air temperature, relative humidity, and solar radiation, from the Crary $1 \mathrm{E}$ weather station were used. Specific conductance values measured in the spring of 2009 by the USGS for Dry Lake (USGS streamflow-gaging station 05056241 , not shown on figure 1, located 5 miles north of site 3), Lake Irvine (USGS streamflow-gaging station 05056260 , not shown on figure 1, located 5 miles northwest of site 2) and Little Coulee (site 4; fig.1) were used as constant boundary conditions for Big Coulee, Channel A and Little Coulee, respectively (U.S. Geological Survey, 2009). For scenarios 2 and 4, a volume-weighted mean was used to determine a SC concentration of $634 \mu \mathrm{S} \mathrm{cm}^{-1}$ (table 9). Because the only continuous water temperature available for inflows was from the 2006 data-collection effort, 2006 daily temperatures were specified for Big Coulee (site 2) and Channel A (site 3), respectively (table 9). Daily temperature data were not available for Little Coulee, so the daily time series from site 2 was used. The model grid was divided into seven areas for specifying initial SC concentration (fig. 20).

For year 1, initial conditions for SC for each bay were determined from 2009 samples collected quarterly on Devils Lake by the North Dakota Department of Health, and Stump Lake (site 13) by the USGS (North Dakota Department of Health, 2010; U.S. Geological Survey, 2009). An initial SC concentration for April 1 was determined by linearly interpolating between samples collected in the winter and the spring for an individual bay. Following the first year of simulation, the SC and water level on October 1 were used as the initial conditions in each bay for the following year.

To quantify the effects of hydrological modification on dissolved solids concentrations, the simulated mean SC concentrations for West Bay and Main Bay for scenarios 2, 3 , and 4 were compared to the simulated mean concentration for scenario 1 (table 10). The simulated mean concentration for West Bay for scenario 1, for the 4-year period, was 2,050 $\mu \mathrm{S} \mathrm{cm}-1$. It is important to note that because the transport of dissolved solids was not calibrated, this mean concentration is not an actual expected value. However, relative to scenario 1, mean concentrations in West Bay for scenarios 2 and 4 were reduced by approximately 9 percent (table 10). Further mean concentrations in West Bay near the North Dakota State Outlet, were reduced by about 10 percent (table 10). In contrast,

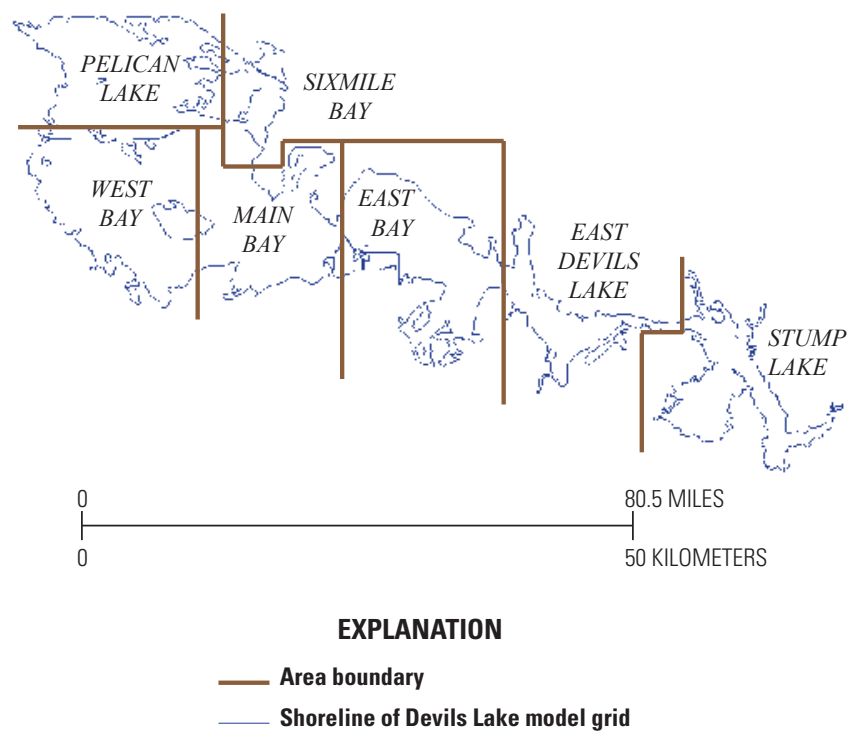

Figure 20. Areas in the model grid of the Devils Lake model, North Dakota used for specifying initial specific conductance concentrations. 
Table 10. Simulated effects of hydrological modifications on specific conductance concentrations for West Bay and Main Bay in Devils Lake, North Dakota.

\begin{tabular}{|c|c|c|c|}
\hline Location & $\begin{array}{c}\text { Mean, } \\
\text { in microsiemens } \\
\text { per centimeter }\end{array}$ & $\begin{array}{l}\text { 95-percent confidence } \\
\text { interval for mean, } \\
\text { in microsiemens } \\
\text { per centimeter }\end{array}$ & $\begin{array}{l}\text { Change in concentration } \\
\text { from base condition, } \\
\text { in percent }\end{array}$ \\
\hline \multicolumn{4}{|c|}{ Scenario 1-baseline condition (no hydrological modification) } \\
\hline West Bay & 2,050 & 1.22 & -- \\
\hline West Bay near North Dakota State Outlet & 2,040 & 1.21 & -- \\
\hline Main Bay & 2,110 & 1.21 & -- \\
\hline \multicolumn{4}{|c|}{ Scenario 2-diversion of Channel A } \\
\hline West Bay & 1,870 & 2.14 & $-8.8^{a}$ \\
\hline West Bay near North Dakota State Outlet & 1,830 & 2.21 & -10.3 \\
\hline Main Bay & 2,300 & .38 & $9.0^{\mathrm{b}}$ \\
\hline \multicolumn{4}{|c|}{ Scenario 3-reduction of the area of water exchange between Main Bay and East Bay } \\
\hline West Bay & 2,050 & 1.3 & 0 \\
\hline West Bay near North Dakota State Outlet & 2,040 & 1.27 & 0 \\
\hline Main Bay & 2,070 & 1.38 & -1.9 \\
\hline \multicolumn{4}{|c|}{ Scenario 4-a combination of scenarios 2 and 3} \\
\hline West Bay & 1,860 & 2.2 & -9.3 \\
\hline West Bay near North Dakota State Outlet & 1,820 & 2.27 & -10.8 \\
\hline Main Bay & 2,270 & .42 & 7.6 \\
\hline
\end{tabular}

${ }^{a}$ Negative change indicates a reduced concentration relative to scenario 1.

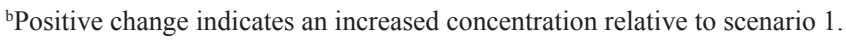

relative to scenario 1, mean concentrations in Main Bay were increased slightly for scenarios 2 and 4.

For scenario 3, there was no change in concentration for West Bay relative to scenario 1, but the mean concentration in Main Bay was reduced slightly. Given that there is no change in concentration for scenario 3 in West Bay, but about a 9-percent reduction in concentration for scenario 4 , the diversion of Channel A was the only hydrologic modification that appeared to have the potential to reduce sulfate concentrations in West Bay.

\section{Summary}

The Devils Lake Basin is a 3,810-square-mile subbasin of the Red River of the North. The basin is closed when water levels of Devils Lake are less than $1446.5 \mathrm{ft}$ above the National Geodetic Vertical Datum of 1929. Devils Lake has been experiencing an unprecedented rise in water levels. The U.S. Geological Survey, in cooperation with the North Dakota Department of Transportation, North Dakota State Water Commission, and U.S. Army Corps of Engineers, developed a two-dimensional hydrodynamic model of Devils Lake and
Stump Lake, North Dakota to be used as a hydrologic tool for evaluating the effects of different inflow scenarios on water levels, circulation, and the transport of dissolved solids. The numerical model, UnTRIM, and data primarily collected during 2006 were used to develop and calibrate the Devils Lake model. Hydrologic conditions in Devils Lake during 2006 were described using water-level, water-velocity, and flow data collected throughout the lake. Performance of the Devils Lake model was tested using 2009 data. The Devils Lake model was applied to evaluate the effects of an extreme flooding event on water levels and hydrological modifications within the lake on the transport of dissolved solids through Devils Lake and Stump Lake.

In 2006, the largest volume of inflow into Devils Lake occurred during April and May because of spring runoff. The total estimated annual inflow to the entire Devils Lake Basin (which includes ungaged inflows) in 2006 was about 242,000 acre- $\mathrm{ft}$, which is slightly less than the annual average of 244,000 acre-ft for 1993-2009. In 2006, water levels in Devils Lake varied seasonally and were affected by wind. The maximum water level at site 1 occurred in the spring on May 9, 2006, at an elevation of 1,449.20 ft above National Geodetic Vertical Datum 1929, and water levels fell over the course of the summer to a level of 1,447.30 ft on September 30, 2006. 
Depending on wind speed, wind direction, and duration of strong winds, a difference of up to about $0.25 \mathrm{ft}$ in water levels occurred between sites located at opposite ends of the lake.

Because the Devils Lake model was to be used for simulating the maximum water level at site 1 for an extreme flood, particular emphasis was placed on accurately simulating water levels in Devils Lake. Calibration was achieved by adjusting net daily evaporation, Manning's $n$ in the bottom friction formulation, and surface drag coefficient in the surface friction formulation. For the 2006 calibration, simulated water levels in Devils Lake compared well with measured water levels. The maximum simulated water level at site 1 was within 0.13 feet of the maximum measured water level in the calibration, which gives reasonable confidence that the Devils Lake model is able to accurately simulate the maximum water level at site 1 for the extreme flooding scenario. The timing and direction of wind-driven fluctuations in water levels on a short time scale (a few hours to a day) were reproduced well by the Devils Lake model. For this application, the Devils Lake model was not optimized for simulation of the current speed through bridge openings. In future applications, simulation of current speed through bridge openings could be improved by accurate definition of the bathymetry and geometry of select areas in the model grid.

As a test of the performance of the Devils Lake model, a simulation of 2009 conditions from April 1 through September 30, 2009, was performed. Measured inflows for Big Coulee and Channel A were not available in 2009, so daily inflows for the tributaries of Big Coulee and Channel A were estimated from a model of the chain of lakes from the National Weather Service. Overall, errors in inflow estimates affected the results for the 2009 simulation; however, for the rising phase of the lakes, the Devils Lake model more accurately simulated the faster rate of rise in Devils Lake than in Stump Lake, and timing and direction of wind-driven fluctuations in water levels on a short time scale were reproduced well.

To help the U.S. Army Corps of Engineers (USACE) determine the elevation to which the protective embankment for the city of Devils Lake should be raised, an extreme flooding scenario based on an inflow of one-half the probable maximum flood was simulated. For design purposes, the USACE assumed an inflow equivalent to one-half the probable maximum flood or 1.44 million acre-feet to the Devils Lake Basin. The initial water level for the extreme flooding scenario was 1,458.0 feet above National Geodetic Vertical Datum of 1929 for both lakes, which is the elevation at which water overflows from Stump Lake. To accommodate overflow from Stump Lake, an outlet to Tolna Coulee was defined in the model grid. Under the conditions and assumptions of the extreme flooding scenario, the water level for both lakes reached a maximum water level around 1,461.9 ft feet above National Geodetic Vertical Datum 1929. To test the sensitivity of water-level results to the assumed conditions for the extreme flooding scenario, four simulations were made in which certain conditions were changed. Water-level results were most sensitive to an increase in the Manning's $n$. The maximum water level in Devils Lake was increased by $0.2 \mathrm{ft}$ when the Manning's $n$ was increased to 0.06 . Water-level results were insensitive to bridge and road modifications as indicated by the small change in water levels.

One factor limiting the extent of pumping from the Devils Lake State Outlet is sulfate concentrations in West Bay. If sulfate concentrations can be reduced in West Bay, pumping from the Devils Lake State Outlet potentially can increase. The Devil Lake model was used to simulate the transport of dissolved solids using specific conductance data as a surrogate for sulfate. Because the transport of dissolved solids was not calibrated, results from the simulations were not actual expected concentrations. However, the effects of hydrological modifications on the transport of dissolved solids could be evaluated by comparing the effects of hydrological modifications relative to a baseline scenario in which no hydrological modifications were made. Four scenarios were simulated: (1) baseline condition (no hydrological modification), (2) diversion of Channel A, (3) reduction of the area of water exchange between Main Bay and East Bay, and (4) combination of scenarios 2 and 3. Relative to scenario 1, mean concentrations in West Bay for scenarios 2 and 4 were reduced by approximately 9 percent. Given that there is no change in concentration for scenario 3 , but about a 9-percent reduction in concentration for scenario 4 , the diversion of Channel A was the only hydrologic modification that appeared to have the potential to reduce sulfate concentrations in West Bay.

\section{References Cited}

Aronow, Saul, 1957, On the postglacial history of the Devils Lake region, North Dakota: Journal of Geology, v. 65, no. 4, p. $410-427$.

Bluemle, J.P., 1991, Radiocarbon dating of beaches and outlets of Devils Lake: North Dakota Geological Survey Miscellaneous Series 75, $10 \mathrm{p}$.

Casulli, V., 1990, Semi-implicit finite-difference methods for the two-dimensional shallow water equations: Journal of Computational Physics, v. 86, p. 56-74.

Casulli, V., and Cheng, R.T., 1992, Semi-implicit finite difference methods for three-dimensional shallow water flow: International Journal for Numerical Methods in Fluids, v. 15, p. 629-648.

Casulli, V., and Cattani, E., 1994, Stability, accuracy and efficiency of a semi-implicit method for three-dimensional shallow water flow: Computers \& Mathematics with Applications, v. 27, p. 99-112.

Casulli, V., and Lang, G., 2004, Technical report mathematical model UnTRIM validation document, v. 1.0, $78 \mathrm{p}$. 
Casulli, V., and Walters, R.A., 2000, An unstructured grid, three-dimensional model based on the shallow water equations: International Journal for Numerical Methods in Fluids, v. 32, p. 331-348.

Cheng, R.T., Casulli, V., and Gartner, J.W., 1993, Tidal, residual, intertidal mudflat (TRIM) model and its applications to San Francisco Bay, California: Esturarine, Coastal and Shelf Science, v. 36, p. 235-280.

Chow, V. E., 1959, Open channel hydraulics: McGraw-Hill Book Company, Inc., New York, 680 p.

Farnsworth, R.K., Thompson, E.S., and Peck, E.L., 1982, Evaporation atlas for the contiguous 48 United States: U.S. Department of Commerce National Oceanic and Atmospheric Administration, National Weather Service, NOAA Technical Report NWS 33, Washington, D.C., 26 p.

Gill, A.E., 1982, Atmosphere-ocean dynamics: Academic Press, New York, 662 p.

Hill, K.D., Dauphinee, T.M, and Woods, D.J., 1986, The extension of the Practical Salinity Scale 1978 to low salinities: Institute of Electrical and Electronics Engineers Journal of Oceanic Engineering, v. 11, p. 109-112.

Komor, S.C., 1994, Bottom-sediment chemistry in Devils Lake, northeast North Dakota: Society of Economic Paleontologists and Mineralogists Special Publication No. 50, p. 21-32, accessed December 2, 2010, at http://nd.water.usgs. gov/pubs/abs/abs386.html.

Lent, R.M., 1994, Sources and cycling of major ions and nutrients in Devils Lake, North Dakota: U.S. Geological Survey Water-Resources Investigations Report 94-4171, 63 p., accessed December 2, 2010, at http://pubs.er.usgs.gov/pubs/ wri/wri944171.

Lippert C., and Sellerhoff, F., 2006, Efficient generation of orthogonal unstructured grids: Proceedings of the Seventh International Conference on Hydroscience and Engineering, Philadelphia, Pa., 2006: Philadelphia, Drexel University, accessed December 20, 2009, at http://idea.library.drexel. edu/handle/1860/1472.

Morlock, S.E., Nguyen, H.T., and Ross, J.H., 2002, Feasibility of acoustic doppler velocity meters for production of discharge records from U.S. Geological Survey streamflowgaging stations: U.S. Geological Survey Water-Resources Investigations Report 01-4157, $56 \mathrm{p}$.

Mueller, D.S., and Wagner, C.R., 2009, Measuring discharge with acoustic Doppler current profilers from a moving boat: U.S. Geological Survey Techniques and Methods 3A-22, 72 p. Also available at http://pubs.water.usgs.gov/tm3a22.
Murphy, E.C., Fritz, A.K., and Fleming, R.F., 1997, The Jerusalem and Tolna outlets in the Devils Lake Basin, North Dakota: North Dakota Geological Survey Report of Investigation No. 100, 36 p.

North Dakota Department of Health, 2010, Chemical, physical, and biological characterization of Devils Lake, 19952009, accessed March 3, 2010, at http://www.ndhealth.gov/ WQ/SW/Z7_Publications/LakeReports/DVLKRPT2009 Final.pdf.

North Dakota State Water Commission, 2010, Devils Lake Flood Facts, accessed August 27, 2010, at http://www.swc. state.nd.us/4DLink9/4dcgi/GetContentPDF/PB-194/Outlet Quick_Facts.pdf.

Northern Prairie Wildlife Research Center, 2010, Climate of North Dakota-wind, accessed September 7, 2010, at http:// www.npwrc.usgs.gov/resource/habitat/climate/wind.htm.

Rantz, S.E. and others, 1982, Measurement and Computation of Streamflow: Volume 1, Measurement of Stage and Discharge: U.S. Geological Survey Water-Supply Paper 2175, $284 \mathrm{p}$.

Report of the Federal Interagency Devils Lake Working Group, accessed January 20, 2011, at http://asacw.hqda. pentagon.mil/documents/DevilsLakeReportFINAL.pdf.

Ryan, G.L and Wiche, G.J., 1988, Hydrology of the chain of lakes tributary to Devils Lake and water-level simulations of Devils Lake, northeastern North Dakota: U.S. Geological Survey Water-Resources Investigations Report 88-4020, 39 p. Also available at http://pubs.er.usgs.gov/pubs/wri/ wri884020.

U.S. Geological Survey, 2009 Data Report, accessed September 14, 2010, at http://wdr.water.usgs.gov/wy2009/search. jsp.

Vecchia, A.V., 2002, Simulation of a proposed emergency outlet from Devils Lake, North Dakota: U.S. Geological Survey Water-Resources Investigations Report 02-4042, 129 p. Also available at http://nd.water.usgs.gov/pubs/wri/ wri024042/index.html.

Vecchia, A.V., 2008, Climate simulation and flood risk analysis for 2008-40 for Devils Lake, North Dakota: U.S. Geological Survey Scientific Investigations Report 2008-5011, 28 p. Also available available at http://pubs.er.usgs.gov/ usgspubs/sir/sir20085011.

Wiche, G.J., 1994, Hydrology of the Devils Lake area, North Dakota: North Dakota State Water Commission Water Resources Investigation 22, $24 \mathrm{p}$. 
Wiche, G.J., 1986, Hydrologic and climatologic factors affecting water levels of Devils Lake, North Dakota: U.S. Geological Survey Water-Resources Investigations Report 86-4320, 62 p. Also available at http://pubs.er.usgs.gov/ pubs/wri/wri864320.

Wiche, G.J., Vecchia, A.V., Osborne, L., Wood, C.M., and Fay, J.T., 2000, Climatology, hydrology, and simulation of an emergency outlet, Devils Lake Basin, North Dakota: U.S. Geological Survey Water-Resources Investigations Report 00-4174, $16 \mathrm{p}$.

Wood, T.M., 2009, Preliminary study of the effect of the Long Lake Valley Project operation on the transport of larval suckers in Upper Klamath Lake, Oregon: U.S. Geological Survey Open-File Report 2009-1060, 24 p. Also available at http://pubs.usgs.gov/of/2009/1060/.

Wood, T.M., Cheng, R.T., Gartner, J.W. Hoilman, G.R., Lindenberg, M.K., and Wellman, R.E., 2008, Modeling hydrodynamics and heat transport in Upper Klamath Lake, Oregon and implications for water quality: U.S. Geological Survey Scientific Investigations Report 2008-5076, 48 p.

Wu, J., 1969, Wind stress and surface roughness at air-sea interface: Journal of Geophysical Research, v. 74, p. $444-455$. 
Publishing support provided by:

Rolla Publishing Service Center

For more information concerning this publication, contact:

Director, USGS North Dakota Water Science Center

821 East Interstate Avenue

Bismarck, North Dakota 58503

(701) 250-7400

Or visit the North Dakota Water Science Center Web site at: http://nd.water.usgs.gov/ 

